\title{
Under adels- og hertugstyre
}

Hørup og Ulkebøl sogne indtil ca. 1670

\section{af Henning Mathiesen}

Hertug Hans den Yngre i Sønderborg har fået et slemt eftermæle: Han nedlagde bøndergårde på stribe og pålagde sine bønder nye afgifter. I denne artikel søger regnskabschef Henning Mathiesen, Sønderborg, at efterprøve overleveringen. Med udgangspunkt i de to sogne Hørup og Ulkebøl og på grundlag af samtidige kilder belyser han landbrugsstrukturen $i$ de to sogne indtil omkring $1670 \mathrm{og}$ når frem til, at forholdene under hertug Hans den Yngre nok ikke var meget værre end mange andre steder, men at de blev forringet under hertugens efterkommere.

\section{Indledning}

I bogen "Hertugens Folk «' redegøres for de administrative, økonomiske og sociale forhold for landbrugerne under de to hovedgårde Rønhave og Sønderborg Ladegård $\mathrm{i}$ tiden fra ca. $1640 \mathrm{og}$ indtil den begyndende udskiftning $\mathrm{i}$ tiden omkring 1770 .

I denne tid var begge hovedgårde samlet under én herre, forst den sønderborgske hertug, derefter kronen og til sidst den augustenborgske hertug.

Sådan havde det imidlertid ikke altid været, og det kan derfor være interessant at undersøge, hvordan landbrugsstrukturen har været, inden hovedgårdene blev forenede og drevet sammen, samt hvordan hertug Hans den Yngre og hans efterfølgere har påvirket landsbyerne og dermed rammerne for landbrugernes virke.

De to hovedgårde Rønhave og Sønderborg Ladegård omfattede alle driftsenheder i Ulkebøl og Hørup sogne med undtagelse af Mintebjerg, der fra 1640 var henlagt under Majbølgård.

Den følgende redegørelse vil omfatte forholdene for alle driftsenheder i de to sogne - altså også Mintebjerg.

\section{Førreformatorisk adel i området}

I den sene middelalder har landbrugsstrukturen i de to sogne nok været den samme som andre steder i Danmark: Landbrugernes driftsenheder kunne deles $\mathrm{i}$ tre kategorier, nemlig almindelige gårde, som man enten kunne eje eller fæste, brydegårde og mindre landejendomme - gårdsædebrug. 
"Bønderne« (dvs. selvejerne) ejede selv deres gård, og »landboerne« fæstede den af ejeren. "Bryderne« var forpagtere på en som regel større driftsenhed. Endelig havde "gårdsæderne« en mindre landejendom og kan nærmest sammenlignes med det, der i en nyere tid er defineret som kådnere eller husmænd.

Bryderne drev landejendommene for ejerens regning, men der var intet til hinder for, at man kunne have jord både som selvejer og som fæester; dette begreb kaldes $\mathrm{i}$ jyske lov fra 1241 for en "fælligbryde «.

Ejeren af en fæste- eller brydegård var som regel en adelsmand, en kirkelig institution eller kronen.

De adelige ejere var pligtige til at yde ros- og krigstjeneste for deres undersåtter; mange mindre adelige godsejere eller væbnere kunne ikke på længere sigt klare denne økonomiske forpligtelse og faldt derfor tilbage $\mathrm{i}$ bondestanden. ${ }^{2}$

Den første godsejer af denne type, der kendes fra de to omhandlede sogne, er Peter Stød, der den 6. oktober 1397 på Urnehoved sammen med de førende gejstlige og adelige $\mathrm{i}$ hertugdømmet var med til at bevidne overdragelsen af hertuginde Elisabeth af Mecklenborgs gods til hertug Gerd af Slesvig. Det er i øvrigt første gang, holstenske og slesvigske adelige var samlede i fælles anliggende.

Peter Stød nævnes som den eneste uden titelangivelse, og han anføres sidst i opremsningen, hvor han var den eneste repræsentant for Sønderborg-egnen. ${ }^{3}$ Han har imidlertid været væbner (latin »armiger«), hvilket fremgår 18. april 1400 , hvor han sammen med sin hustru Catherina stiftede et vikarie (sidealter) til den hellige jomfru Marias alter i St. Jørgens kapel i Sønderborg. ${ }^{4}$

Overdragelsen omfattede gårde i Ragebøl (årlig ydelse 2 øre korn) og Dybbøl (1 øre) på Sundeved, Sjellerup ( 2 øre korn) og Notmarkskov (årlig ydelse 2 øre korn) på Als samt 3 ørtug land på Sønderborgs ubebyggede bymark (»campo Sunderborgh «), der årligt gav 6 øre korn. I Ulkebøl blev overdraget 2 gårde, besiddet af Nesse Topessen og Nisse Jespessen, der tilsammen ydede 6 øre korn årligt. Overdragelsen blev 1423 ud over vikariets evige præst, Johannes de Alkendorp, bekræftet af den slesvigske grev Gerd, ${ }^{5}$ hvilket kan forekomme besynderligt, eftersom størstedelen af ydelsen lå på Als, der i kirkelig henseende hørte under Odense stift (og dermed kongeriget), hvilket også blev præciseret i dokumentet.

Peter Stød er muligvis identisk med den Peter Stød, der i 1380'erne nævnes som borger og 1394 som rådmand i Ribe; 1454 fik en person af samme navn (muligvis søn eller sønnesøn) Ertebjerggård i forlening, ${ }^{6}$ og i begyndelsen af 1600-tallet nævnes en herredsfoged af samme navn i Nordborg. Noget kunne tyde på, at slægten gradvis er faldet tilbage til den almene bondestand.

Peter Stød har ikke efterladt sig synlige spor i lokalområdet, men det skal 
bemærkes, at en gård ved udflytningen fra Ulkebøl i 1793 fik navnet "Stødager« efter den mark i nærheden af Sønderborg, gården kom til at ligge på.

En anden adelsmand fra Ulkebøl var Claus Petersen, der ejede gården Bagmose. Han må være identisk med den "Claues Peterson de terra Alse lande«, der omkring midten af 1400-tallet nævnes som medlem af St. Laurentii gildet i Flensborg, ${ }^{7}$ ligesom han også var medlem af St. Gertruds gildet i Flensborg, ${ }^{8}$ hvor han sammen med 7 andre medlemmer i 1464 bevidnede regnskabsaflæggelsen. ${ }^{9}$

Han må imidlertid være kommet i pengeforlegenhed, for i 1466 pantsatte han sin ejendom til forstanderne for St. Peters, St. Pauls og St. Erasmi vikariet ved St. Nicolai-kirken i Sønderborg for 100 mark lybsk. ${ }^{10}$ Gården ydede som de fleste brydegårde - en usædvanlig høj landgilde, nemlig 16 ørtug korn (hundrede år senere 5 ørtug byg og 11 ørtug havre).

Gården må have været befæstet, for i 1866 blev der i forbindelse med ombygningen af den nuværende gård Bagmose fundet en ca. $15 \mathrm{~m}$ bred og indtil $1 \mathrm{~m}$ dyb grav, der lå $\mathrm{i}$ en vinkel øst og vest for stuehuset. "

Lavadelige som Peter Stød og Claus Petersen boede oftest i det lokalområde, hvor de havde deres gods. De har næppe adskilt sig væentligt fra den almindelige bondestand.

En anden og betydeligt mere kendt adelsslægt med et befæstet anlæg i Ulkebøl' ${ }^{12}$ var familien Holck. Selve slægten kan føres tilbage til 1300-tallet, og den har fra 1400-tallet haft besiddelser i sognet.

I en plovskatfortegnelse fra $1506^{13}$ nævnes Bertel Holck, der var den første i familien, der skrev sig til Rønhave, med 4 plove. Han var søn af Godske Holck, og hans brødre Hartvig (til Ballegård) og Wulf (til Mjelsgård) nævnes i samme fortegnelse med hhv. 7 og 14 plove.

Fra Hørup sogn kendes ingen egentlige adelsslægter, men fra en senere tid kan ses, at slægten Sture, der ejede såvel Gammelgård som Helvedgård, havde adskillige ejendomme i sognet. 1506 nævnes brødrene Wulf og Henrik, der var sønner af Thomas Sture, med i alt $42 \frac{1}{2}$ plove under de to hovedgårde. ${ }^{14}$

Endelig var der kongens gods. Selve krongodset (feudum) tilhørte monarken i egenskab af hertug af Slesvig, medens de gårde, kongen erhvervede på anden måde, blev besiddet som en kongerigsk enklave i hertugdømmet.

Således købte kong Hans den 14. juni 1507 bl.a. to gårde i Lambjerg og 2 gårde samt 1 kåd $\mathrm{i}$ Vollerup fra væbneren Niels Bjørnsen af Nielstrup. ${ }^{15}$ De to gårde $\mathrm{i}$ Lambjerg ydede hver 6 ørtug korn - de to gårde $\mathrm{i}$ Vollerup det samme tilsammen.

$\mathrm{Og}$ af Kirstine Jensdatter, enke efter Verner Pedersen, købte han bl.a. gårde beliggende i Lambjergskov, Hørupskov og Vollerup samt "Kymeres møllestædt«, der dog var øde. ${ }^{16}$ 


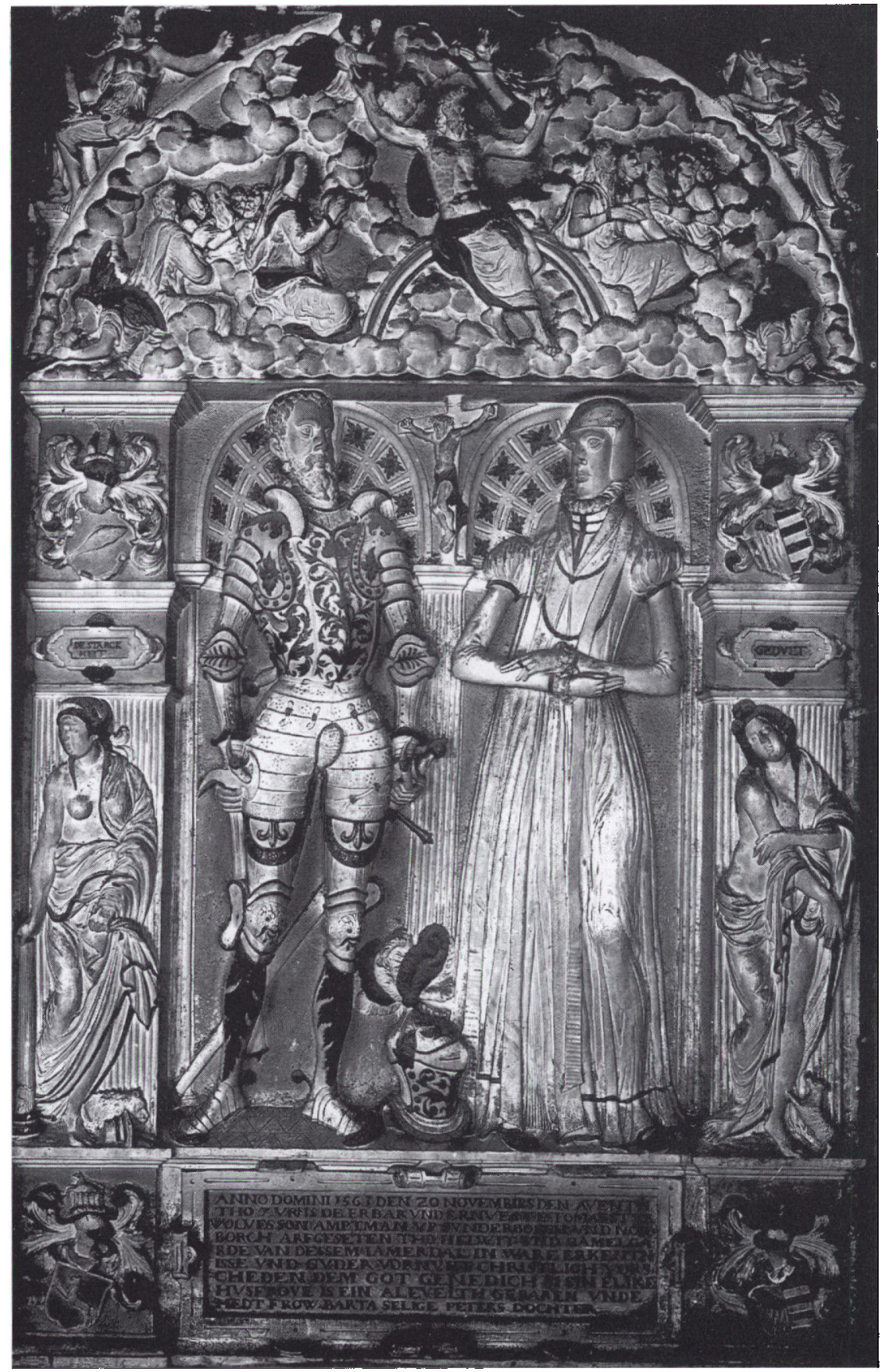


Og i jordebogen fra $1524^{17}$ nævnes 2 landboer $i$ Vollerup, som kongen havde købt af Bertel Holck, samt en gård i Mjang, en i Mintebjerg og 3 i Majbøl, som kongen havde fået af biskoppen på Fyn. Ti år senere nævnes også en landbo i Ulkebøl, erhvervet fra Wulf Sture. ${ }^{18}$

Selv om mange mindre adelige ikke har efterladt sig spor i de bevarede arkivalier fra tiden før reformationen, må sammenfattende siges, at adelsgodset har haft et relativt begranset omfang og typisk karakter af strøgods, der vanskeliggjorde hoveri, hvorfor "godsherskabet", hvor godsejeren primært satsede på store hovedgårdsmarker, drevet af hovbønder, ikke var særlig udbredt. Fæsteforholdet var derfor et regulært jordlejeforhold ("grundherskab«), hvor godsejeren fortrinsvis fik betaling i naturalier. ${ }^{19}$ Således hedder det i biskoppen af Slesvigs jordebog 1509-15, at fæsterne på Als bragte kornet til havnen, hvorfra det blev fragtet ad søvejen til Slesvig. Landbrugerne skulle selv fragte kornet, men omkostningerne blev delt mellem landbrugerne og bispen. ${ }^{20}$

Allerede 1354 fik ejerne af fæstegods i Sønderborg-området dog ret til bøder op til et beløb af 3 mark, ${ }^{21}$ hvilket var en af forudsætningerne for hovedgårdsdrift og godsherskab; den væsentligste forudsætning - samlede jordtilliggender var dog endnu ikke til stede på reformationstiden.

\section{Det kirkelige gods}

Også den katolske kirke havde - som overalt i kongeriget og hertugdømmerne - gods i området. Dette gods var primært doneret som sjælegaver af adelige.

Den tidligste overdragelse af denne art må have fundet sted under kong Valdemar den Store, idet hans kansler, abbed Niels, der døde ca. 1234, overdrog sine besiddelser i Ulkebøl og Lysabild til domkapitlet i Slesvig; i Ulkebøl drejede det sig ifølge jordebogen fra 1352 om en ejendom på 1 otting samt 3 gårdsæder. I tiden omkring 1450 ydede den ene ejendom årligt 2 øre korn, de tre mindre hver 2 ørtug korn. 22

En anden tidlig overdragelse fra området blev foretaget $\mathrm{i}$ året 1306, hvor Mæ, enke efter Meinseth i Ulkebøl, skænkede Ryd kloster noget ikke nærmere specificeret jordegods - med en dengang almindelig klausul om, at det aldrig måtte afhændes! ${ }^{23}$

I kongeriget har Kr. Erslev anslået, at kronens indtægter blev tredoblet efter inddragelsen af kirkegodset. ${ }^{24}$ Der har dog næppe været så meget kirkeligt 
gods $\mathrm{i}$ hertugdømmerne, idet der $\mathrm{i}$ landsdelen dels var flere selvejere end $\mathrm{i}$ kongeriget, ligesom der allerede 1390 blev indført et forbud mod at testamentere gårde i byerne og på landet til kirken og de gejstlige. ${ }^{25}$

Men som med så mange love var der naturligvis en vej uden om - man kunne f.eks. overlade godset $i$ levende live til brug for kirken efter arveladerens død som ved Peter Støds nævnte overdragelse fra år 1400 til St. Jørgens kapel; det derved beliggende hospital nævnes første gang 1307 i forbindelse med en pengegave. ${ }^{26}$ Kapellet lå som andre kapeller viet til den samme helgen uden for bygrænsen. ${ }^{27}$

I Sønderborg var der også en anden kirke, købmandskirken ${ }^{28}$ viet til St. Nicolai, der $\mathrm{i}$ lighed med de til samme helgen viede kirker i nabobyerne Flensborg og Aabenraa lå placeret $\mathrm{i}$ byens udkant. ${ }^{29} \mathrm{Her}$ var der to altre, der var viet til hhv. St. Gertrud og St. Erasmi. Det førstnævne alter nævnes at have fået jordegods fra de to slesvigske hertuger Valdemar V. Erikssøn (død 1364) og Henrik (død 1375), der 1340-75 residerede i Sønderborg, og fik 1473 sine privilegier bekræftet af kong Christian I. ${ }^{30}$ Bortset fra Claus Petersens pantsættelse 1466, kendes altrenes jordegods først fra en senere tid.

Også mange velhavende adelige valgte at »købe« et lukrativt præsteembede til en eller flere af sønnerne for derved både at sikre deres fremtid og samtidig muliggøre at der blev et rimeligt stort gårdtal til de øvrige. Således blev Peter Sture præst i det vel nok mest vellønnede embede på Als, Lysabild. ${ }^{31}$ Og Bertel Holck til Rønhave har åbenbart haft tilsvarende planer med sin søn Henrik, der 1523 i en alder af kun 18 år af pave Hadrian VI fik løfte om at få rådighedsretten til sognekirkerne i Sønderborg og Ulkebøl mod at han skulle lade sig præstevie inden 7 år. ${ }^{32} \mathrm{Han}$ blev dog fem år senere indskrevet ved universitetet i Wittenberg, hvor han må være kommet i kontakt med kredsen omkring Martin Luther ${ }^{33}$ - og herefter var han tabt for den katolske kirke.

De lokale kirker ejede også jordegods - ofte både inden- og udensogns. Der er dog ikke bevaret optegnelser over dette gods fra tiden før reformationen.

Specielt ved det kirkelige gods kan det $\mathrm{i}$ øvrigt på basis af de bevarede opgørelser være forbundet med vanskeligheder at afgøre ejendommenes omfang, idet der i jordebøgerne som regel kun næunes, hvad der blev betalt $\mathrm{i}$ afgifter. Afgifterne kunne være landgilde for en stor eller lille gård, for en enkelt toft eller en ager - eller det kunne være for en mindre del af en ejendom, der ellers med hensyn til »herlighedsretten« hørte under kronen eller en adelsmand. 


\section{Reformationen og de ændrede ejerforhold}

Der er skrevet meget om reformationen og om dens betydning for samfundsudviklingen, og $\mathrm{i}$ alle redegørelser fremstilles såvel kong Frederik I som hans søn, kong Christian III, som dybt religiøse mennesker, der havde de bedste intentioner for den gejstlige udvikling.

Reformationen betød imidlertid også, at landsherren blev øverste kirkefyrste, hvorved han fik rådighedsretten til det tidligere kirkelige gods. Det danske monarki befandt sig $\mathrm{i}$ årene efter kong Christian II's afsættelse $1523 \mathrm{i}$ en dyb økonomisk krise, og man må erkende, at reformationen kom særdeles belejligt for den betrængte monark og hans økonomiske rådgivere. Det har utvivlsomt også haft sin betydning for nogle af de overvejelser, der blev gjort!

En del af det jordegods, der blev inddraget fra kirkerne, blev givet til efterkommerne af de adelige, der havde ydet gaver til kirkerne, medens kongen endvidere og ofte med rund hånd - forærede jordegods til andre adelige som tak for hjælp af den ene eller anden art. Således forærede kong Frederik I 1528 franciskanernes kloster i Flensborg til Mogens Gjøe, ${ }^{34} \mathrm{og}$ året efter bortgav kongen en gård, der havde hørt under St. Nikolai-kirken i Sønderborg, til Wolmar van der Herberge som tak for dennes tro tjeneste ${ }^{35}$ - vel nok den første transaktion af den art i Fyns stift, hvortil øen Als havde hørt siden 1287.

Denne praksis synes dog ret hurtigt at være stoppet, idet reformatoren Martin Luther i 1536 tilskrev kongen og anmodede ham om at holde kirkegodset intakt, således at man derved kunne sikre indtægter til kirkernes vedligeholdelse og opretholdelse af klostrenes almennyttige formål. ${ }^{36}$

Der kendes dog fortsat eksempler på, at kongen har givet årlige ydelser af kirkens gods til særligt begunstigede. Således tildelte kong Christian III i 1548 Magdalene Sture indtægten af 1 læst korn af Ulkebøl kirkes jord, hvilket hendes moder, Sofie Holck, der var en søster til Manderup Holck fra Barritskov og siden 1513 enke efter Claus Sture, havde haft før hende. ${ }^{37}$

Ud over foræringer og køb af adelsgods fik adelen også i noget omfang mulighed for at foretage mageskifter, hvorved der blev muligt at arrondere strøgodset til samlede tilliggender, der muliggjorde en egentlig hovedgårdsdrift.

Der er som tidligere næunt desvære ikke bevaret et fuldstændigt materiale over adelsgodsets omfang til forskellig tid, men tager man de oven for nævnte adelige, der bevisligt havde gods i Hørup eller Ulkebøl sogne og som nævnes ved opkrævningen af plovskat i $1506^{38}$ og sammenligner deres afgifter med dem, der blev betalt $1534,{ }^{39}$ ses tydeligt en kraftig udvikling i det antal plove, der blev betalt afgift for: 
1506 plove i alt:

Wulf og Henrik Sture

Hartvig Holck

van der Herberge

Bertel Holck
1534 plove $i$ alt:

$\begin{array}{ll}\text { Wulf Sture } & 70 \\ \text { Godske Holck } & 19 \\ \text { Jg. og Wolmer v.d. Herberge } & 14 \\ \text { Bertel Holck } & 10\end{array}$

Tallene må ikke tages som absolutte størrelser. Da skattefortegnelserne ikke er specificerede, kan det ikke udledes, hvor de nyerhvervede gårde er beliggende eller hvorfra de er kommet, eller om der var tale om ejede eller forlenede gårde; således erhvervede Bertel Holck 1519 nogle gårde fra sin onkel, Manderup Holck..$^{40}$

I 1550 efterkom Christian III i øvrigt Martin Luthers råd om at sikre almennyttige institutioner ved at oprette en fond, der skulle sikre løn til de ansatte i købstaden Sønderborg. ${ }^{41}$ Dette skete ved at overdrage årlige kornydelser fra et antal tidligere kirkelige gårde til pastoren, kapellanen samt skolemesteren $\mathrm{i}$ købstaden; specielt synes det, som om kapellanen (for Sjellerups vedkommende skolemesteren) har fået størstedelen af kornydelserne fra de gårde, der halvandet århundrede tidligere blev overdraget af Peter Stød.

Denne tidlige overdragelse beviser også, hvilken bevågenhed kongen havde over for Sønderborg. Den langt større købstad Flensborg fik således først en tilsvarende overdragelse året efter. ${ }^{42}$

I kongeriget har allerede Kristian Erslevs undersøgelser vist, at adelen fik relativt lidt udbytte af det inddragne kirkelige gods. ${ }^{43}$ I hertugdømmerne der-

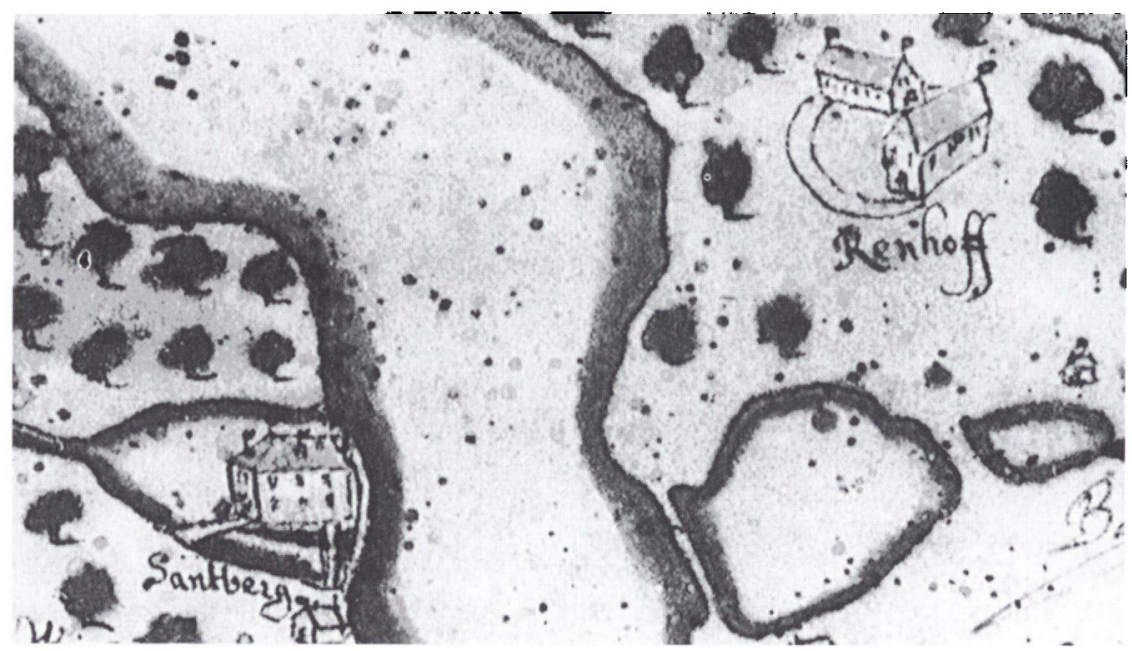

Runhave pả Kar-halvoen er gengivet pà Heinrich Ottendorffs landkort 1655. Sy'd for gärden ses en storre og mindre so. Det er resterne af den tidligere Kar vig, som hertug Hans $d$. Yngre med en damning lod adskille fra Alssund. Foto Det kgl. Bibliotek, jwfr. Jorgen Paulsen i Fra Als og Sundeved bd. 68. 
imod fandt inddragelsen sted under kong Frederik I, og her fik adelen nok en større del af jorden. Frederik I havde reelt heller ikke andre økonomiske muligheder for at aflønne den adel, han var afhængig af, end ved at overlade dem dele af det tidligere kirkelige gods.

Adelens forøgede godsmængde samt mageskifter gjorde det muligt at etablere samlede jordtilliggender, der ved ægteskab kunne samles på færre hænder. Især hvor gårdene lå $\mathrm{i}$ umiddelbar nærhed af hovedgårdene, som f.eks. ved Rønhave, var der basis for en egentlig hovedgårdsdrift, hvilket dog ikke synes at have været almindeligt i Ulkebøl sogn. Sture's hovedgård »Gammelgård" lå således i Ketting sogn, og godsets besiddelser i Hørup sogn synes fortsat at have haft karakter af strøgods.

Heller ikke på kronens ladegård i Sønderborg synes der at have fundet hovedgårdsdrift af større omfang sted. I midten af 1530'erne høstede man årligt 3-4 last (à 24 ørtug) korn, mest rug, som bønderne ikke ydede i landgilde, men også byg og i meget begrænset omfang (1535) havre.

Af køer havde man 1535 og 1536 hhv. 62 og 65, der gav hhv. $4 \frac{3}{4}$ og $4 \frac{1}{2}$ tønder smør. Året efter næunes et svinehold på over $1.000 .^{44}$

Ladegården havde på det tidspunkt endnu ikke noget egentligt navn, men benævnes blot "Vorwarck « ${ }^{45}$ og selv om man i 1542 betalte 12 tømrere i alt 110 mark 10 skilling for at bygge en ny lade, ${ }^{46}$ er hovedgårdsdriften næppe blevet intensiveret af den grund - i ca. 1560 nævnes således en udsæd på 20 tønder (=ørtug) ${ }^{47}$ korn og et kreaturhold på 30 køer og 50 får. $^{48}$

\section{Udviklingen i gårdtal 1483-1543}

De tidligste egentlige optegnelser om indbyggerne i Hørup og Ulkebøl sogne er skattefortegnelser.

Landsherren skulle oprindelig »bede« om en ekstraordinær skat, og 1483 blev denne bevilget med 1 gulden $(11 / 2$ mark) pr. plov. Pengene gik til at indfri den gæld, kong Christian I havde til adelen $\mathrm{i}$ hertugdømmerne! ${ }^{49} 3$ år senere lød opkrævningen på 1 mark pr. plov. 1514 var taksten igen 1 gulden, og i de urolige år omkring borgerkrigen $\mathrm{i}$ kongeriget blev der opkrævet 1 mark i 1533, 2 gulden i 1533, i 1536 blev der opkrævet 2 gange 1 gulden. 1542 var satsen helt oppe på 4 gulden og året efter $3 \frac{1}{2} 2$ mark pr. plov.

På basis af disse skattefortegnelser kan der udfærdiges opgørelser, der viser udviklingen $\mathrm{i}$ besiddere og driftsenheder (tabel 1), idet der flere steder optræder to ejere på nogle af driftsenhederne; dette tidligere ret almindelige forhold forsvinder kort efter år 1500, hvilket blev fremmet af lovgivningen..$^{50}$

Ligeledes kan der på basis af afgiftssatserne foretages en beregning, der viser, hvor mange plove, der blev betalt skat for (tabel 2). Sammenholdes disse 
Tabel 1. Antal besiddere/driftsenheder i Horup og Ulkebol sogne 1483-1543, beregnet på basis of plovskattefortegnelser

\begin{tabular}{lrrrrrrrrr}
\hline & 1483 & 1486 & 1514 & 1533 & 1535 & 1536 I & 1536 II & 1542 & 1543 \\
\hline Hørupskov & $6 / 5$ & 5 & 4 & 5 & 4 & 5 & 5 & 4 & 4 \\
Lambjergskov & 12 & $11 / 10$ & 5 & 5 & 5 & 5 & 5 & 5 & 5 \\
Lambjerg & $10 / 9$ & 12 & 5 & 6 & 5 & 5 & 5 & 5 & 5 \\
Mjang & 2 & 2 & 2 & 7 & 7 & 7 & 7 & 7 & 7 \\
Knarmose & 4 & 4 & 7 & 8 & 2 & 2 & 2 & & \\
Majbøl & $11 / 9$ & 8 & 7 & 8 & 8 & 8 & 6 & 7 & 7 \\
Mintebjerg & $45 / 41$ & $42 / 41$ & 37 & 41 & 38 & 39 & 36 & 35 & 35 \\
\hline Hørup sogn i alt & & & & & & & & & \\
\hline & $24 / 22$ & $28 / 25$ & 19 & 19 & 18 & 18 & 18 & 17 & 17 \\
Ulkebøl/Kær & 13 & 12 & 12 & 11 & 11 & 11 & 11 & 11 & 11 \\
Sundsmark & $15 / 13$ & 15 & $15 / 131 / 2$ & 17 & 16 & 16 & 15 & 16 & 16 \\
Vollerup & $9 / 8$ & $10 / 8$ & $8 / 5$ & 8 & 8 & 8 & 8 & 8 & 8 \\
Klinting & $61 / 56$ & $65 / 60$ & $54 / 491 / 2$ & 55 & 53 & 53 & 52 & 52 & 52 \\
\hline Ulkebøl sogn i alt & & & & & & & & &
\end{tabular}

to tabeller ses, at man fra 1530 'erne fik det mønster, der i området kendes helt op til udskiftningstiden, nemlig at bol er lig med plov.

\section{De Sønderborgske hertuger}

\section{a. Hertug Hans den Yngre}

I 1564 blev kong Christian III's yngste søn Hans hertug i 1/3 af kongens del af hertugdømmerne, hvilket fik stor betydning for Sønderborg-egnen. Hans

Tabel 2. Antal kontribuerende plove i Horup og Ulkehol sogne 1483-154, beregnet på basis of plovskattefortegnelser

\begin{tabular}{lrrrrrrrrr}
\hline & 1483 & 1486 & 1514 & 1533 & 1535 & 15361 & 1536 II & 1542 & 1543 \\
\hline Hørupskov & 5,9 & 6,1 & 3,0 & 5,0 & 4,0 & 4,5 & 4,5 & 4,0 & 4,0 \\
Lambjergskov & 13,4 & $15,8\}$ & 4,8 & 5,1 & 5,0 & 5,4 & 5,4 & 5,0 & 5,0 \\
Lambjerg & 6,3 & 8,5 & 5,1 & 6,0 & 5,0 & 5,0 & 5,0 & 5,0 & 5,0 \\
Mjang & 5,0 & 5,1 & 2,3 & 2,7 & 2,4 & 2,3 & 2,3 & & \\
Knarmose & 2,0 & 2,4 & 5,8 & 8,0 & 7,0 & 7,0 & 6,0 & 7,0 & 7,0 \\
Majbøl & 10,5 & 9,9 & 7,5 & 8,0 & 8,0 & 8,0 & 5,8 & 7,0 & 7,0 \\
Mintebjerg & 43,1 & 47,8 & 35,3 & 41,8 & 38,0 & 38,2 & 35,7 & 35,0 & 35,0 \\
\hline Hørup sogn i alt & & & & & & & & & \\
\hline & 31,5 & 32,6 & 20,2 & 19,8 & 18,0 & 18,0 & 18,0 & 17,0 & 17,0 \\
Ulkebøl/Kær & 10,2 & 9,5 & 10,3 & 11,5 & 10,8 & 11,2 & 11,2 & 11,0 & 11,0 \\
Sundsmark & 16,6 & 18,3 & 14,6 & 18,4 & 16,0 & 16,0 & 15,0 & 16,0 & 16,0 \\
Vollerup & 10,8 & 12,1 & 6,8 & 7,9 & 8,0 & 7,7 & 8,0 & 8,0 & 8,0 \\
Klinting & 69,1 & 72,5 & 51,9 & 57,6 & 52,8 & 52,9 & 52,2 & 52,0 & 52,0 \\
\hline Ulkebøl sogn i alt & & & & & & & & &
\end{tabular}


hertugdømme kom til at bestå af Sønderborg og Nordborg amter, og desuden i Holsten byen og slottet Plön samt Ahrensbök kloster. ${ }^{51}$

Det gods, der blev overladt hertugen, er ikke på nogen måde specificeret, men det anføres, ${ }^{52}$ at det var med waller Zubehörung, Herrligkeit und Gerechtigkeitt erblich zugetheilet und überwiesen«.

Hertug Hans var dog langtfra eneherre i området, hvor der fortsat var en talstærk adel, ligesom moderen, enkedronning Dorothea, havde indtægterne fra Als som livgeding indtil sin død i $1571 .{ }^{53}$

På Als viste manglerne ved overdragelsen i 1564 sig meget hurtigt, idet hertug Hans kun skulle overtage kronens gods på øen, medens moderen også havde haft indtægterne af kongens gods, dvs. det gods, kongen og hans forgængere havde købt eller mageskiftet sig til samt den tilbageblevne del af det gods, der var blevet inddraget fra den katolske kirke i forbindelse med reformationen.

Af dette gods havde dronning Dorothea i 1565 overdraget rettigheder resp. ydelser fra nogle gårde til det allerede eksisterende St. Jørgens hospital, ${ }^{54} \mathrm{der}$ i forbindelse med reformationen havde mistet størstedelen af sit eksistensgrundlag, således også indtægterne fra Peter Støds gårde. Efter dronningens død 6

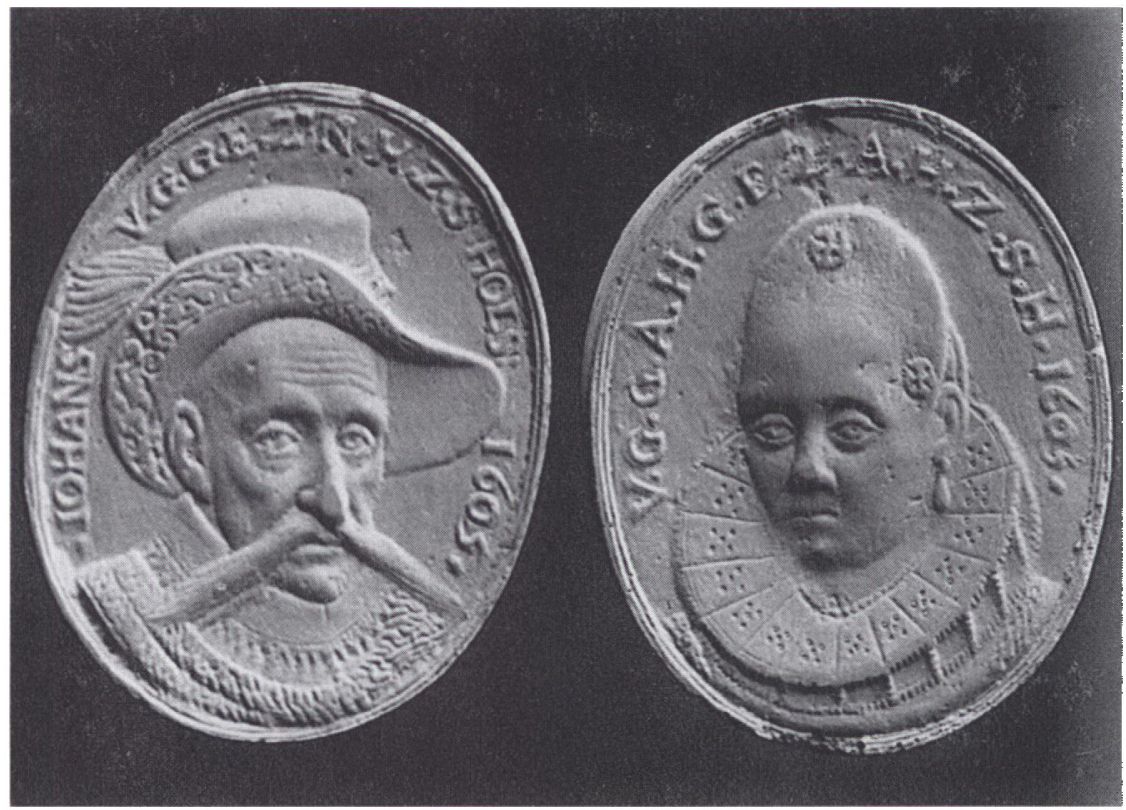

Hans den Yngre og hertuginde Agnes Hedwig. Portratmedaljer i Montkabinettet $i$ Gotha 1605. Foto $i$ Historiske Samlinger. 
år senere blev kongens gods henlagt under amtmanden i Nyborg, der også fik tilsynet med de kirkelige stiftelser. ${ }^{55}$

For hertug Hans betød det, at han ud over en del ret spredt adelsgods også måtte acceptere kongens tilstedeværelse på Als. Da hertugen forsøgte at få retten til de kongelige undersåtters tjenesteydelser tilkendt, måtte han 1572 lide den tort at se sig fradømt retten hertil af Knut Clausen, wherredsfoged over landets ting", herredsfoged Asmus Kate fra Als sønder herred samt 12 menige bønder, der meddelte, at deres "Huerdenst « altid var blevet lagt til Fyn med undtagelse af tjenerne under St. Gertruds alter samt kirketjenerne, der siden Manderup Holcks tid som amtmand i Sønderborg havde ydet arbejdet til »dem Huse Sunderborch «. ${ }^{56}$ Dette vederlag har nok været med til at intensivere hertugens arbejde med at udvide sine besiddelser og sit jurisdiktionsområde.

I 1573 mødtes hertug Hans med sin broder, kong Frederik II, i Dronningborg ved Randers. Hertugen forsøgte at få wherlighederne« til kirkens gårde samt den gejstlige jurisdiktion over Als, hvilket kun lykkedes med hensyn til 15 landboer, ${ }^{57}$ der havde hørt til den katolske kirke på Als og af kong Christian III var blevet henlagt til skolen i Sønderborg i 1550 under forbehold af »Hure, Denst, Veste, Bröche, Gerichte, Högest, middelst und Syders mit aller andern Herrligkeit wo de heden und Nahmen hebben « ${ }^{58}$

Ordningen var imidlertid kun gældende »In dieser vorstehenden Erndten «, idet man ville afvente en uvildig kommissions beretning om forholdene; den gejstlige jurisdiktion over øen fik hertugen dog aldrig! ${ }^{59}$

I slutningen af 1570 'erne købte hertugen noget strøgods på Als og Sundeved, og da hertug Hans den Ældre af Haderslev døde 1580 uden at efterlade sig livsarvinger, skulle Frederik II og hertug Hans på den ene side dele arven med deres farbroder, hertug Adolph af Gottorp på den anden side. Sidstnævne skulle have halvdelen, kongen en trediedel og hertug Hans en sjettedel. For hertug Hans blev resultatet, at han i 1582 fik tillagt Ryd og Reinfeld kloster, noget strøgods og et større pengebeløb. ${ }^{60}$

Strøgodset blev mageskiftet med kongen til erhvervelse af dennes rettigheder til de tidligere kirkelige gårde på $\mathrm{Als},{ }^{61}$ medens pengene bl.a. anvendtes til at købe Helvedgård og Gammelgård på Als af Hans Blome, der til gengæld fik forpagtning på Plön i 4 år for et meget favorabelt beløb af 1.500 mark pr. år. ${ }^{62}$

Også de følgende år oftede Hertug Hans betydelige summer på at udkøbe adelen i sit hertugdømme, og i hhv. 1590 og 1600 lykkedes det ham at købe de to sidste egentlige hovedgårde på Als, nemlig Ronhave, ${ }^{63}$,som han allerede havde forsøgt at erhverve $\mathrm{i}$ forbindelse med delingen efter hertug Hans den Eldre $^{64}$ og Søbo på Nordals, som han købte af Detlev von Rumohr ${ }^{65}$ og 
efterfølgende kaldte Rumohrsgård. I alt købte hertugen gods for langt over 700.000 rdlr., heri ikke beregnet de mageskifter, han foretog gennem årene. ${ }^{66}$

Hertugen mødte imidlertid også modgang. I 1582 døde ca. 400 indbyggere i Sønderborg købstad af pest, ${ }^{67}$ hvilket vel nok har svaret til godt $20 \%$ af byens daværende befolkning. Også købstadens omegn blev udsat for »den sorte død«, og landbrugsjorden på Als blev derfor i 1585 opmålt og på »ærlig måde frataget nogle og tillagt andre, ligesom der er sket forandringer på grund af befolkningens dødelige afgang «, som det hedder i en samtidig jordebog. ${ }^{68}$ Dette havde imidlertid efter alt at dømme også den virkning, at hertugen kunne arrondere sine hovedgårde og egalisere undersåtternes afgifter.

\section{b. Gårdnedlæggelser 1543-1602}

Umiddelbart efter århundredskiftet havde hertug Hans samlet næsten hele Als, og en jordebog fra ca. $1602^{69}$ giver sammenholdt med opgørelserne fra 1500tallets første halvdel et billede af godsstrukturen under hertugen, jfr. tabel 3.

I de bevarede naturalieregnskaber anføres 3 bol i Majbøl og 1 i Miang at stamme fra biskoppen på Fyn ${ }^{70}$, men på basis af pengeafgifterne i 1500-tallet kan man ikke altid kan se, om det drejer sig om et blandet tilhørsforhold, om et bol eller et kåd. ${ }^{71}$ I mageskiftet ${ }^{72}$ nævnes gårde dog med betegnelsen "Höfe«, medens personer, der nævnes uden angivelser og kun betalte mindre afgifter (typisk 6 sk. jagtpenge og 2 favne træ) er tjenere med et »blandet« tilhørsforhold og inkluderet $\mathrm{i}$ hertugens oprindelige gods. De er derfor ikke medtaget $\mathrm{i}$ tabellen.

I Ulkebøl sogn kan de enkelte driftsenheder i stort omfang identificeres fra 1543 på basis af uændrede pengeydelser. I Hørup sogn har der imidlertid fundet en større egalisering sted, således at kun selvejernes pengeydelser er uændrede i perioden; der kan derfor også være gårde, der henregnes til en anden landsby end oprindelig.

\section{Horup}

I Hørup angiver tabel 3, at to bol er forsvundet fra 1543 til 1602, men det kan ikke afgøres, hvilke det drejer sig om, eller om det er en følge af egaliseringen. To af de syv bol, der blev erhvervet 1584 betalte således kun 3 ørtug korn hver, hvilket er omkring halvdelen af, hvad de andre ydede.

\section{Lambjerg/Lambjergskov}

I Lambjerg nævnes 1602 i alt 9 landboer (inkl. Bendiktris, der havde hørt under Gammelgård) med pengeydelser. 


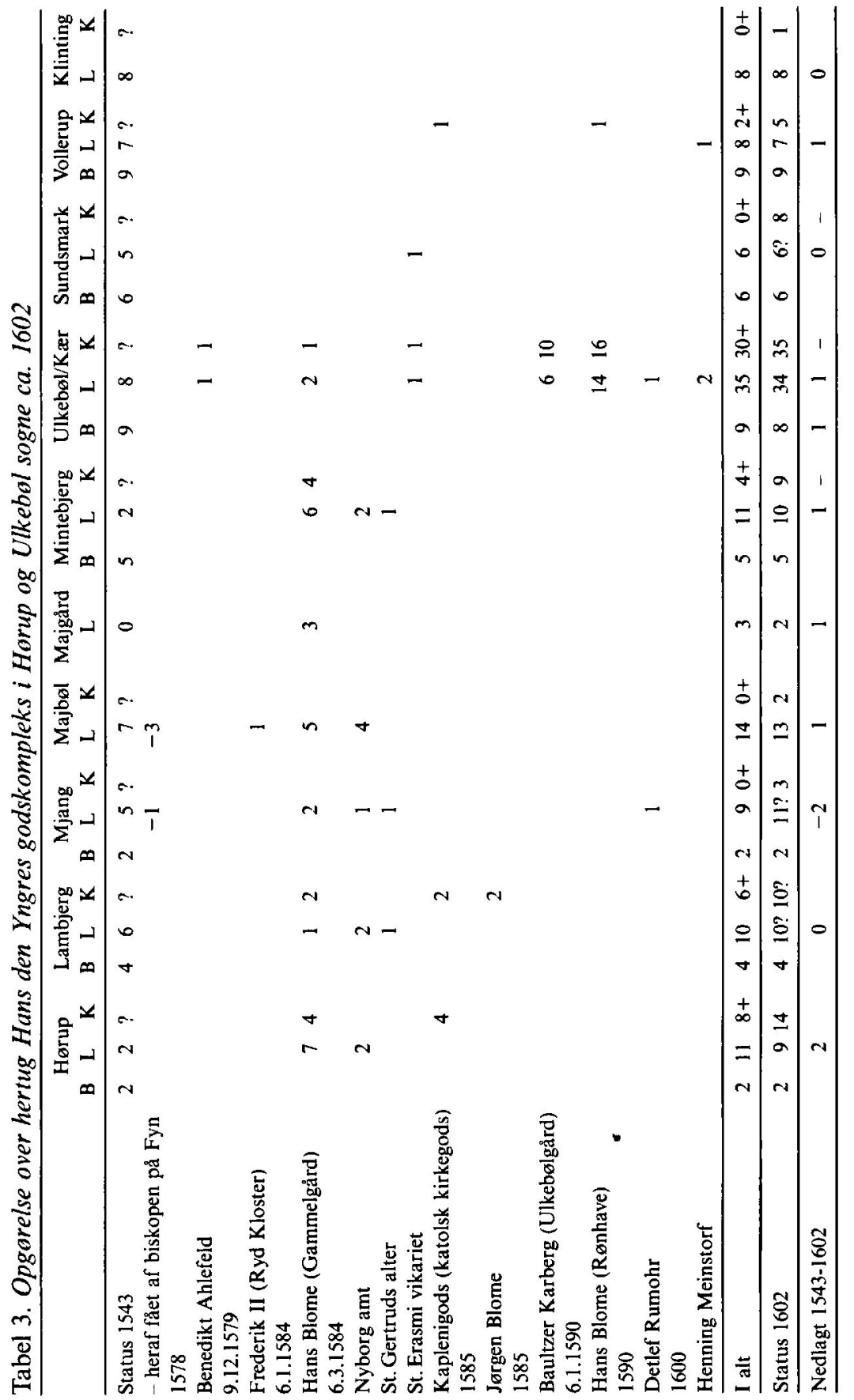


Regnskabet omhandler kun driftsenheder, der betalte pengeafgifter, og da der på et senere tidspunkt nævnes et bol, der udelukkende betalte naturalieydelser, synes alle bol fortsat at være intakt.

Et af bolene blev dog drevet af alle indbyggere i fællesskab, og da en kådner betalte 12 skilling i afgift for "et halvt øde bol«, lader det til, at en ødegård er blevet gjort til et kåd, medens jorden er henlagt under hovedgården eller fordelt mellem de andre bol, som det også kendes fra Sjælland. ${ }^{73}$ Ødelæggelsen må dog have fundet sted, længe inden hertug Hans overtog alle gårdene.

\section{Mjang}

I Mjang nævnes der $1602 \mathrm{i}$ alt 10 landboer. Det synes imidlertid, som om et bol ekstra har været midlertidig ubesat, idet der på et senere tidspunkt nævnes 11, jfr. neden for, og noget tyder derfor på, at der er »opstået « to nye bol inden år 1602. De kan være overført fra Herup.

\section{Majbol}

I Majbøl synes der at være ødelagt ét bol, men af de 4 bol, der nævnes 6 . marts 1584, var det ene delt mellem to landboer (den ene betalte for $11 / 2$ bol, den anden, der 1571 nævnes som hertug Hans' tjener, ${ }^{74}$ har muligvis været en kådner). Altså ingen ødelæggelser under hertug Hans den Yngre.

\section{Majgård}

I Majbøl er det "lille« bol, der kun ydede 3 ørtug korn i landgilde, blevet nedlagt mellem 1584 og 1602.

\section{Mintebjerg}

I Mintebjerg er det tilkøbte allodialgods intakt 1602 , og det bol, der savnes 1602 må således findes blandt de to oprindelig kongelige bol eller blandt kirkegodset.

\section{Ulkebol/Kar}

Landsbyen Kær næunes første gang $1573,{ }^{75}$ men gårdene i landsbyen nævnes ofte under Ulkebøl, med hvilken man havde mark- og dyrkningsfællesskab indtil udskiftningen. Alle driftsenheder i de to landsbyer er blevet henlagt under hovedgården Rønhave, hvortil der ikke hørte landbrugere fra andre landsbyer.

I Ulkebøl/Kær er der 1602 forsvundet ét selvejerbol, idet det anføres, at Jørgen Koch's bol er øde og henlagt til hovedgården Rønhave, og det samme anføres ved et af de fæstebol, hertugen havde overtaget efter Holck'erne, nemlig Hans Clausen.

Selvejerbolet var det i de to sogne, der ydede den laveste afgift på reforma- 
tionstiden, medens Hans Clausen ved overtagelsen i 1590 nævnes med den laveste afgift af de 5 bol i Ulkebøl (kornafgiften androg 2/3 af de andres).

De $\mathrm{i}$ forbindelse med erhvervelsen af Rønhave nævnte 3 bol i Skovhuse ses ikke nævnt $\mathrm{i}$ jordebogen og må derfor være henlagt under hovedgården.

I Ulkebøl kirkes ældste regnskabsbog, udarbejdet 3 måneder før hertug Hans købte Rønhave af Hans Blome, næunes ingen af de fire landboer, som optræder i skødet, men som 12 år senere var øde. Gårdene må derfor allerede have været øde ved hertugens overtagelse af hovedgården, og hertug Hans har derfor reelt ikke - som det hedder i traditionen - nedlagt landsbyen som sådan!

Kirkegodset kan som næunt ikke bestemmes entydigt, men i forbindelse med arronderingen synes der at være henlagt kirkeligt gods under skolen og St. Jørgens hospital fra Sønderborg købstad til Ulkebøl, jfr. således, at den landgilde, der hhv. 1550 og 1565 nævnes betalt af 4 resp. 1 person i Sønderborg $^{76}$ senere betales af indbyggerne i Ulkebøl, ${ }^{77} \mathrm{og}$ disse gårde synes at være erhvervet sammen med Ulkebølgård; et bol forblev dog til disposition som tjenestejord for borgmesteren i Sønderborg og er ikke indregnet i det boltal, der nævnes 1602. Ulkebøl sogn synes således at have fået sit areal udvidet på Sønderborgs bekostning i forbindelse med arronderingerne.

Alt $\mathrm{i}$ alt har hertug Hans således kun nedlagt et lille selvejerbol. Yderligere 4 landboer under Rønhave er forsvundet, før hertugen fik rådighed over hovedgården, men når der i tabel 3 kun anføres netto én landbo som ødelagt, skyldes dette dels tilgangen af bol fra Sønderborg samt at den tidligere kirkelige gård Bagmose - som også traditionen vil vide ${ }^{78}$ - er blevet delt $i$ to. Altså er »kun« ét selvejerbol og (netto) ét fæstebol blevet ødelagt.

\section{Sundsmark}

I Sundsmark nævnes kun selvejere i 1602, idet jordebogen kun angiver pengeafgifterne, og ingen af fæsterne betalte penge på reformationstiden. Men i et regnskab over, hvor mange svin, indbyggerne på Als måtte have gående på Kegnæs, nævnes 11 bolsmænd, ${ }^{79}$ og i Ulkebøl kirkes tienderegister fra $1589^{80}$ er tallet 10 ekskl. det bol, der hørte til St. Jørgens hospital.

Det ser derfor ud til, at ét bol er forsvundet. Det må være en selvejer, der ikke har været i drift, men som alligevel anføres i skattefortegnelsen med Hans Nielsen som besidder. Det var således endnu 1602 ikke nedlagt, men holdt $\mathrm{i}$ "reserve«, jfr. neden for.

\section{Vollerup}

I Vollerup savnes 1602 én driftsenhed. Den nævnes 1543 at være besiddet af Hans Jepsen, der ifølge landgildefortegnelsen betalte 10 skilling for en toft og således ikke for et helt bol. Altså formentlig ingen ødelæggelser. 


\section{Klinting}

Traditionen siger, at da der engang forsvandt et stykke flæsk på Sønderborg slot, fik hertug Hans mistanke til indbyggerne fra Klinting, der havde gjort hoveri på slottet. En bolsmand, der hed Brock, var lovlig undskyldt, idet han havde været syg, men de øvrige syv ${ }^{81}$ blev hængt som straf for tyveriet. Af landbrugernes jord oprettede han Sønderborg ladegård. Næste forår skulle kødet være fundet $i$ voldgraven omkring slottet, hvorfor hertugen angrede ved at bygge de tre ens udseende kirker i Adsbøl i Sundeved, Nykirke i Angel og Kegnæs på Als.

Efter kornafgifterne at dømme har de 8 bol i Klinting været større i senmiddelalderen end i tiden efter hertug Hans, hvor de også er blevet egaliserede med en ret lille kornydelse. Selve boltallet nævnes ikke i regnskabet fra 1602, men $\mathrm{i}$ det to år yngre svineregnskab ${ }^{82}$ anføres 8 personer, hvoraf ingen hed Brock(!) og som havde i alt 85 svin gående i skoven ved Stenholt. De anføres som "kådnere«, men bliver i yngre regnskaber betegnet halvbolsmænd. Dette tal synes ikke at bekræfte overleveringen, selv om ladegårdens arealer nok er blevet udvidet på landsbyens bekostning. Måske var dette baggrunden for sagnet.

\section{Hovedgärdene}

Medens alle bolsmænd og kådnere i Ulkebøl/Kær som nævnt er blevet henlagt under Rønhave, er alle øvrige indbyggere i Ulkebøl og Hørup sogne henlagt under "Sønderborg len«, der også omfattede indbyggere i Vibøge, Taskland, Vibæk, Sarup, Lebøl og Pommersgård; hovedgården synes endnu ikke i 1602 at have haft noget navn.

Efter gennemgangen må konkluderes, at der i perioden 1543 til 1602 er nedlagt ét af de 37 selvejerbol i området, medens netto mindst 3 (i Mintebjerg, Majgård, Ulkebøl) og højst 7 af de mulige 125 fæstebol er blevet ødelagte. Det svarer til en ødelæggelsesprocent på mellem $2 \mathrm{og} 5$. Ingen af ødelæggelserne kan entydig tilskrives hertug Hans og kan være foregået, inden han har fået dispositionsretten til området i 1571 . Ifølge hertugens jordebog fra 1602 nævnes kun 2 bol direkte at være ødelagt og henlagt under Rønhave - og dette tal kan udmærket være korrekt!

Nedlæggelserne har således ikke været af et for tiden ret stort omfang, og der kan ikke ses at være foretaget nedlæggelser af bol, der var besat og i drift, som det var almindeligt $i$ kongeriget og som traditionen på Als vil vide det. ${ }^{83}$ De bol, der entydigt ses at være nedlagt, synes at have været enten ubesættelige eller små og urentable. 


\section{c. Hertugdømmet Sønderborg 1622-67}

Hertug Hans døde 1622, og hans hertugdømme blev delt mellem 5 af sønnerne, hvorved der opstod 5 små hertugdømmer, nemlig Plön, Glücksburg, Ærø, Nordborg og Sønderborg. Sidstnævnte gik til den næstældste af sønnerne, Alexander, der var født 1573. Han giftede sig 32 år gammel med Dorothea af Schwartzburg, en niece til grev Johan den Ældre af Oldenburg. Hertug Hans var oprindelig imod ægteskabet, og Alexander fik kun tilsagn om en fast, ålig apanage fra faderen, såfremt ægteparret holdt sig borte fra faderens område! Alexander bosatte sig derfor i nærheden af Minden i Westfalen, hvor han købte herregården Beck.

Apanagen fra faderen var imidlertid ikke tilstrækkelig til at familien kunne opretholde en efter deres forhold rimelig levestandard (der var i ægteskabet 11 børn, alle født i Beck - hertug Hans havde 23!), og Alexander forsøgte derfor at erhverve flere penge ved indtægter fra godsets drift.

Inden hertug Hans døde, bedredes forholdene mellem fader og søn, og måske på grund af Alexanders store børneflok fik han tildelt hertugdømmet Sønderborg, der nok var det største af de fem små hertugdømmer og som gav et årligt afkast på ca. 20.000 dalere i faste pengeydelser, hvortil kom retsbøderne og naturalieydelserne.

Hertug Alexander havde imidlertid allerede inden faderens død måttet låne for at kunne opretholde en hertugelig levestandard, og han nåede ikke at afvikle denne gæld, inden han døde i maj $1627 .{ }^{84}$

Han havde dog åbenbart erkendt sine problemer, for i sit testamente ${ }^{85}$ bestemte han, at hertugdømmet Sønderborg ikke skulle deles mellem de 6 sønner, men udelt gå i arv til den ældste, hertug Hans Christian, der dog ikke måtte gifte sig, inden gælden var afviklet, ligesom han måtte respektere, at moderen skulle forestå hertugdømmets drift.

Undersåtterne har næppe mærket nogen forandring $\mathrm{i}$ hofholdningen på Sønderborg slot, men allerede samme år, som Alexander døde, synes ulykkerne at være brudt ud.

Den danske konge, hertug Alexanders fætter Christian IV, havde i vinteren 1625 mod rigsrådets ønsker og i sin egenskab af hertug af Holsten, meldt sin deltagelse i 30-års krigen - en krig, som hertuginde Dorothea forsøgte at holde sig ude fra ved at erklære sig neutral, selv om hendes sympatier nok skulle findes på kejserens side; hendes broder var således officer i Tilly's hær ${ }^{86}$.

Men over for den danske konge beklagede hun dybt sin akutte pengenød og sin skrøbelighed - to forhold, der uden tvivl var sande ${ }^{87}$ og skulle tjene til undskyldning for Sønderborgs neutralitet.

Da de kejserlige tropper under Tilly og Wallenstein besatte Slesvig, måtte 
hun i 18 uger give tropperne husly, og da de ikke fik sold, men deres underhold var overladt til befolkningen, ${ }^{88} \mathrm{kan}$ man levende forestille sig, at bøndernes ydelser primært er gået til besættelsesmagten.

1628 blev et skib med korn fra Sønderborg, der var bestemt for salg i Lybeck, ydermere beslaglagt af kongelige skibe, der vel med rette mente, hertuginden konspirerede med de fjendtlige, kejserlige tropper. ${ }^{89}$

For at bevise deres loyalitet over for den danske konge måtte indbyggerne på Als affinde sig med at yde indkvartering og underhold til de kongelige tropper efter at Wallensteins regiment i juni 1629 endelig havde forladt området. ${ }^{90} \mathrm{Og}$ denne belastning har ikke været af mindre omfang end de 4 dalere pr. plov ud over naturalier og tjenesteydelser, som Wallenstein i sin instruks af 26. oktober 1628 havde fastsat! $!^{91}$

Lederen af de danske tropper var i øvrigt oberst Henrik Holck, ${ }^{92}$ der var søn af den Detlev Holck, ${ }^{93}$ der sammen med sine brødre i sin tid havde ejet Rønhave.

Bønderne kunne i disse år ikke yde de fulde afgifter, og hertugdømmets ekstraordinært store udgifter sammenholdt med de stærkt reducerede indtægter betød, at gælden voksede stærkt og ikke - som tilstræbt af hertug Alexander - blev nedbragt.

Hertugfamilien enedes derfor i 1633 om, at Hans Christian skulle fritages for faderens testamentariske bestemmelser. I stedet skulle han overtage ledelsen af hertugdømmet mod at udbetale 1.000 dalere årligt til hver af sine fem brødre, yde søstrene forplejning og en standsmæssig medgift ved deres evt. ægteskab, samt lade moderen få »den lille ladegård ved Sønderborg «, frit ophold på slottet og 2.000 dalere årligt. Og året efter kunne den unge hertug gifte sig med Anna, der var datter af grev Anthon af Delmenhorst. ${ }^{94}$

De store ydelser til de mange søskende sammenholdt med den tyngende gældsforpligtelse blev begyndelsen til enden for hertugdømmet, der i 1633 havde en gæld på godt 127.000 dalere. ${ }^{95}$ Dette forhold blev forstærket under Torstenssonskrigen 1643-45, hvor hertugdømmet atter forsøgte at bevare neutraliteten ved at købe sig fri for belejring fra svensk side, men da den danske kongemagt i februar 1645 forsøgte at fordrive svenskerne fra Jylland, blev Als påtvunget indkvartering af 14 kompagnier kongeligt rytteri, der blev på øen i 4 uger til stor belastning for undersåtterne - og til stor irritation for den svenske flåde, der krævede en månedlig kontribution for at fritage hertugdømmet fra at lide overlast. ${ }^{96}$

I forhold til indbyggerne i det øvrige Slesvig må indbyggerne på Als dog siges at være sluppet lempeligt fra krigen. For at skåne de dele, der havde lidt større overlast, blev Als påtvunget indkvartering af kongeligt rytteri i 16 uger, 
hvortil kom de af landdagen bevilgede ekstraskatter, som hertugen dog nægtede at betale. ${ }^{97}$

Hans Christian døde allerede 1653 i en alder af kun 46 år. Hans ældste søn, Christian Adolf, var kun 12 år gammel, og moderen måtte derfor forestå ledelsen af det lille og stærkt forgældede hertugdømme.

Fire år senere kom det imidlertid på grund af forholdene $\mathrm{i}$ kongeriget til den næste krig mod svenskerne, og selv om enkehertuginde Anna forsøgte at opnå neutralitet, måtte hun sidst på året 1657 åbne sit hertugdømme for belejring af svenske tropper, der ifølge et sagn som eneste sold fik lov til at plyndre øens befolkning i tre dage. ${ }^{98}$ Endvidere måtte landbrugerne yde kost til de ca. 2.000 mand $^{99}$ og deres nok mere end 1.200 heste. ${ }^{100}$

Belejringen varede indtil december 1658, hvor øen blev erobret af de danske allierede, de polske og brandenburgske hjælpetropper, der dog ikke var mildere $i$ deres behandling af undersåtterne, end svenskerne havde været det. ${ }^{101}$

Således beretter en samtidig kilde, at de allierede plyndrede selv fattiggården, hvor der efter deres indfald hverken var ko eller kalv, kedel eller gryde tilbage. Heller ikke landbrugerne var i stand til at yde noget korn, hvorfor man havde været nødsaget til at købe brød og $ø 1$ hos bagere og bryggere. ${ }^{102}$

Landbrugerne forsøgte ofte at slippe for plyndringerne ved at sprede halm og fjer på gårdspladsen for at det skulle se ud, som om de allerede var blevet plyndret, og endnu op i nyere tid har man flere steder kunnet fremvise spor af sabelhug og geværkugler $\mathrm{i}$ døre og bjælker, der vidnede om svenskekrigen. ${ }^{103}$ De tre sidste dage, polakkerne var på øen, fik de lov til at plyndre øens befolkning, der dog kunne købe sig fri for godt 70 dalere pr. bol. ${ }^{104}$

Indkvarteringen blev afløst af danske tropper og varede indtil marts 1662 primært fordi den danske kongemagt ikke havde råd til at betale for troppernes underhold! ${ }^{105}$ I krigens spor fulgte en sygdomsepidemi, og sommeren 1661 gav tørke og misvækst med deraf følgende hungersnød. ${ }^{106}$

Samme år overtog den knap 20 årige hertug Christian Adolf styringen af hertugdømmet, hvor de fleste af aktiverne efterhånden var pantsat til adelige långivere, således at han reelt kun ejede slottet og indtægterne af købstaden Sønderborg. Næsten håbløst blev det året efter, hvor panthaverne ${ }^{107} \mathrm{i}$ »den store ladegård bag slottet, Langenvorwerck «, der var hovedlen i hertugdømmet, ville have ladegården udlagt til ejendom, såfremt hertugen ikke betalte sin gæld. ${ }^{108}$

Hertugen stod herefter med store skattekrav fra den siden 1660 enevældige danske konge, fra långiverne, der havde pant $\mathrm{i}$ alle aktiver og indtægtskilder og fra sine nærmeste frænder, repræsenteret ved sin grandonkel, hertug Ernst Günther (stamfader til de augustenborgske hertuger), der krævede ikke-betalte årspenge! ${ }^{109}$ 
Hertug Ernst Günther (1609-89) er den augustenborgske hertugfamilies stamfader. Efter Sonderborg-hertugens konkurs 1667 kunne han udvide sine besiddelser og bygge det forste Augustenborg. opkaldt efter hustruen Augusta af Glücksborg.

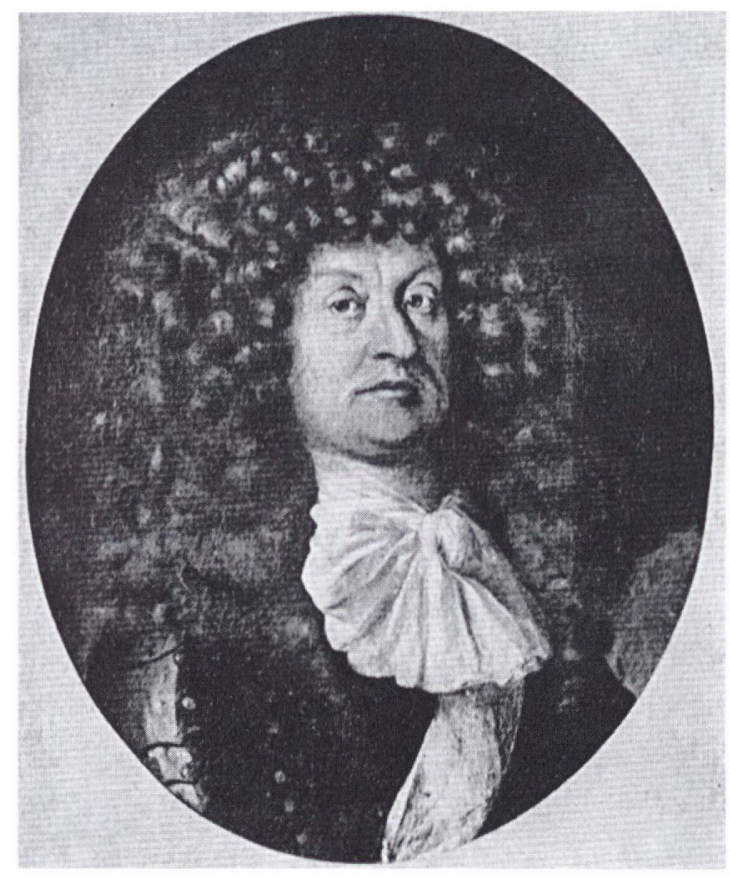

Resultatet af en i februar 1664 nedsat likvidationsdomstol var nærmest givet på forhånd, og den 22. november 1667 blev hertug Christian Adolf fradømt sit hertugdømme, hvis hovedgårde blev udlagt til kreditorerne. ${ }^{10}$ Hertugdømmet var erklæret konkurs!

\section{d. Ændringer i besiddelsestal 1602-1670}

Der er heller ikke fra hertug Hans' efterkommere bevaret noget komplet arkiv, der kan belyse udviklingen inden hertugdømmets konkurs. De eneste fortegnelser over de til lenene hørende landbrugere er to ens pengeregnskaber fra hhv. St. Hans 1642 til St. Hans 1643 og fra denne dato videre til St. Hans $1644^{111}$ - i det følgende benæunt 1643 . De synes pålidelige og nævner også evt. naturalieydelser, der er omregnet til penge, ligesom de giver en del oplysninger om nedlæggelser og nye brug. Endvidere haves et regnskab over penge og naturalier, der på basis af besiddernes navne kan tidsfæstes til ca. 1671, ${ }^{112}$ hvor hovedgårdene efter at have været udlagt til kreditorerne atter er kommet under kronen. ${ }^{113}$

Disse to regnskaber er i tabel 4 sammenholdt med bol- og kådtallet fra 1602 , jfr. ovenfor, og kan give følgende billede af ændringer $i$ antal driftsenheder: 
Tabel 4. Opgorelse af driftsenheder i Horup og Ulkebol sogne 1602-71

\begin{tabular}{|c|c|c|c|c|}
\hline & & 1602 & 1643 & 1671 \\
\hline \multirow[t]{3}{*}{ Hørup } & B & 2 & 2 & 2 \\
\hline & $\mathbf{L}$ & 9 & 8 & 8 \\
\hline & $\mathrm{K}$ & 14 & 16 & 25 \\
\hline \multirow[t]{3}{*}{ Lambjerg } & B & 4 & 4 & 4 \\
\hline & $\mathbf{L}$ & 9 & 9 & 10 \\
\hline & $\mathrm{K}$ & 10 & 8 & 9 \\
\hline \multirow[t]{3}{*}{ Mjang } & B & 2 & 2 & 2 \\
\hline & $\mathbf{L}$ & 10 & 11 & 11 \\
\hline & $\mathrm{K}$ & 3 & 5 & 4 \\
\hline \multirow[t]{2}{*}{ Majbøl } & $\mathbf{L}$ & 13 & 12 & 12 \\
\hline & $\mathbf{K}$ & 2 & 3 & 6 \\
\hline Majgård & $\mathbf{L}$ & 2 & 0 & \\
\hline \multirow[t]{3}{*}{ Mintebjerg } & B & 5 & 4 & 4 \\
\hline & $\mathbf{L}$ & 10 & 8 & 8 \\
\hline & $\mathbf{K}$ & 9 & 11 & 16 \\
\hline \multirow[t]{3}{*}{ Hørup sogn i alt } & B & 13 & 12 & 12 \\
\hline & $\mathbf{L}$ & 53 & 48 & 49 \\
\hline & $\mathbf{K}$ & 38 & 43 & 60 \\
\hline \multirow[t]{3}{*}{ Ulkebøl/Kær } & B & 8 & 8 & 8 \\
\hline & $\mathbf{L}$ & 34 & 34 & 34 \\
\hline & $\mathbf{K}$ & 35 & 33 & 35 \\
\hline \multirow[t]{4}{*}{ Sundsmark } & $F$ & 0 & 1 & 1 \\
\hline & B & 6 & 6 & 5 \\
\hline & $\mathrm{L}$ & $6 ?$ & 5 & 5 \\
\hline & $\mathbf{K}$ & 8 & 9 & 10 \\
\hline \multirow[t]{3}{*}{ Vollerup } & B & 9 & 9 & 9 \\
\hline & $\mathbf{L}$ & 7 & 6 & 6 \\
\hline & $\bar{K}$ & 5 & 8 & 8 \\
\hline \multirow[t]{2}{*}{ Klinting } & $\mathrm{L}$ & 8 & $8 ?$ & 8 \\
\hline & $\mathbf{K}$ & 1 & 1 & 1 \\
\hline \multirow[t]{4}{*}{ Ulkebøl sogn i alt } & $\mathrm{F}$ & 0 & 1 & 1 \\
\hline & B & $23 ?$ & 23 & 22 \\
\hline & $\mathrm{L}$ & $55 ?$ & $53 ?$ & 53 \\
\hline & $\mathrm{K}$ & 48 & 51 & 54 \\
\hline \multirow[t]{4}{*}{ Hele området $\mathrm{i}$ alt } & $\mathrm{F}$ & 0 & 1 & 1 \\
\hline & B & 36 & 35 & 34 \\
\hline & $\mathbf{L}$ & $106 ?$ & $101 ?$ & 102 \\
\hline & $\mathbf{K}$ & 86 & 94 & 114 \\
\hline
\end{tabular}

F: fribol L: landboer $\quad$ B: bol $\quad$ K: kåd

\section{Horup}

I Hørup nævnes 1643, at Nis Jørgensens bol er øde og jorden fordelt mellem de 8 øvrige landboer. Bolet må være nedlagt mellem 1638 og 1643, idet vilkårsbrevet fra førstnævnte år nævner, at der var 11 bolsmænd i landsbyen. 
I Hørup er der i 1631 bygget et nyt kåd, der er mzum windtmühlen hause bei der Mühlen verordnet«, ligesom et kåd på en andens grund nævnes - et såkaldt bondekåd, der i en senere tid blev kaldt et inderstested! 11671 nævnes 25 kåd, hvoraf de 24 angives at være præstekåd.

\section{Lambjerg/Lambjergskov}

I Lambjerg synes det, som om der er oprettet et bol mellem 1643 og 1671, men da de to førstnæunte boltal er angivet på basis af et pengeregnskab og det tredie på basis af et kombineret penge- og naturalieregnskab, ifølge hvilket et enkelt bol ingen pengeafgifter ydede, er tallet reelt uændret i perioden. Gennem hele perioden er en af de nævnte landboer øde, og hele landsbyen betalte en mindre afgift for bolet.

I 1602 betalte en enkelt kådner for »die halbe wüste stelle«, men dette og to andre kåd synes at være forsvundet 1643 . I 1627 er der opbygget et nyt kåd, og mellem 1643 og 1671 er tallet atter forøget med et enkelt.

\section{Mjang}

I Mjang nævnes der ét bol mere end 1602, hvor tallet i pengeregnskabet synes at have været for lavt, jfr. ovenfor. Kådtallet er (netto) steget med ét, der blev oprettet i 1633 »bei der vohlen Koppell zu Gammellgarde«.

\section{Majbol}

I Majbøl er der forsvundet et fæstebol mellem 1602 (eller rettere 1604, hvor 13 landboer havde deres svin gående i skovene på Kegnæs) $)^{114}$ og 1643. Det er gjort til et kåd, og mellem 1643 og 1671 er endnu tre kåd oprettet.

\section{Majgård}

I Majgård er der i 1602 to bol tilbage, som i sin tid hørte under Gammelgård. Det ene blev efter Melchor Sørensen beboet af hertug Ernst Günther (født 1609), en yngre søn af hertug Alexander, for i 1640 at blive omdannet til hovedgården Majbølgård, hvorved også det andet bol i landsbyen blev nedlagt og dets jorder henlagt under den nyoprettede hovedgård.

\section{Mintebjerg}

Også Mintebjerg mærkede oprettelsen af Majbølgård. Et selvejerbol og to fastebol blev i 1640 på hertugens befaling gjort til kåd, medens jorden blev henlagt under hovedgården. Den ene fæstebonde, der blev gjort til kådner, hed Melchor Sørensen, og meget kunne tyde på, at han først har måttet vige bolet i Majgård til fordel for den regerende hertugs onkel for at få et bol i Mintebjerg, som nogle år senere blev gjort til et kåd. En hård skæbne, der dog 
ikke er ukendt fra kongeriget! ${ }^{115}$ Også fire kåd blev ødelagte og henlagt under Majbølgård.

I Mintebjerg var der i 164311 kåd, hvoraf de tre som nævnt var tidligere bol. Endvidere nævnes et kåd at være et nyt bondekåd. Da fire kåd som nævnt er henlagt under hovedgården, er der tale om yderligere to kåd, oprettet efter 1602 - muligvis i 1625 , hvor to af kådnerne nævnes at have fået særjord tillagt. I tiden 1643-71 er tallet steget med yderligere 5 kåd.

\section{Ulkebol/Kar}

I tiden efter 1543 var Ulkebøl/Kær den landsby i området, der blev mest berørt af hovedgårdsomlægningerne, og det er derfor ikke så mærkeligt, at landsbyen har fået lov til at få ro - der er netto ikke sket nogen ændring i tiden 1602-71, idet dog to kåd synes at have været ude af drift $i$ en periode.

\section{Sundsmark}

I Sundsmark blev et fæstebol, der hørte under St. Jørgens hospital, forvandlet til fribol, hvilket skete på en lidt besynderlig måde: Bolet blev 1626 beboet af Hans Frost, men det havde tidligere hørt under Sønderborg, hvor Jobst Petersen og Claus Lauersen (to tidligere borgmestre i købstaden) havde haft bolet. Hertug Alexander solgte (med samtykke fra sin hofpræst, provst Equardi Heshusy, samt inspektør og forstander for fattigkassen) gården til amtsforvalter Hans Jebsen for 2.000 lybske mark inklusive fritagelse for alle afgifter (bl.a. 13 ørtug korn). Med i handelen solgte hertugen også en dam, beliggende »unter dem Galgenbergen damb« (formentlig Mølledammen) for 500 lybske mark et meget højt beløb, når man tager $\mathrm{i}$ betragtning, at Hans Jebsen tidligere havde haft dammen til en årlig afgift (»Haur«) af 4 mark. ${ }^{116}$

I Sundsmark er der i perioden nedlagt et selvejerbol, nemlig dét, der i 1602 betalte den laveste ydelse. Det er i 1602-jordebogen anført at være besiddet af Hans Nielsen, men om ham siger Ulkebøl kirkes restanceliste fra 1589 , at "manden er død og børnene tigger«, hvorfor han ikke er næunt i tiendelisten. ${ }^{117}$ Bolet har derfor nok allerede på den tid været ude af drift, og ifølge et tingsvidne fra $1634^{118}$ er der indgået aftale om, at bolsmændene i Vollerup fik brugsretten mod at græsse ét kræ årligt for sundsmarkerne. Bolet har altså ligget øde i over 80 år, inden der er blevet slettet af jordebogen!

\section{Vollerup}

I Vollerup er et enkelt bol nedlagt 1631, jorden fordelt mellem de øvrige landboere - og der er oprettet to kåd i stedet. Desuden synes endnu et kåd oprettet mellem 1602 og 1643. 


\section{Klinting}

I Klinting har der ikke været ændringer i perioden.

I perioden 1602-71 er der således nedlagt to af de 36 selvejerbol i området, men kun det ene (i Mintebjerg) har været i drift.

I såvel Vollerup og Majbøl synes et øde bol at være gjort til et kåd, og $\mathrm{i}$ Hørup er et enkelt øde bol nedlagt - og dertil kommer de fire fæstebol i Majgård og Mintebjerg, der blev nedlagt for at oprette hovedgården Majbølgård 1640 , og som alle var i drift.

For såvel bønder som landboer betød dette, at $6 \%$ af alle driftsenheder $\mathrm{i}$ perioden 1602-71 er blevet ødelagt - altså væsentligt mere end under hertug Hans den Yngre.

I hele perioden 1543-1671 er der således forsvundet 3 bønder og formentlig mellem 10 og 14 landboer svarende til $8-10 \%$ af områdets bol; der blev ikke foretaget yderligere ødelæggelser inden udskiftningen godt 100 år senere. ${ }^{119}$

For kongerigets vedkommende er Gunnar Olsen kommet til det resultat, at der fandt flere nedlæggelser af bondegårde sted i Jylland end andre steder i landet i perioden 1550-99, og at der i perioden 1525 til 1774 på landsbasis er nedlagt mindst $4,4 \%$ af alle bondegårde $\mathrm{i}$ forbindelse med hovedgårdes oprettelse eller -udvidelse. ${ }^{120}$ På basis af forholdene på Fyn har Erland Porsmose skønnet, at - såfremt også andre nedlæggelsesformer medregnes - tallet er for lavt og nok snarere skal forhøjes til $7 \frac{1}{2} \%$ for den nævnte periode. ${ }^{121}$

Nedlæggelserne i de to sogne Hørup og Ulkebøl ligger derfor en smule over landsgennemsnittet, hvilket krige og besættelser har været medvirkende til. Men det synes, som om der har hersket hårdere forhold under hertug Hans' efterkommere end under den hertug, der om nogen er blevet karakteriseret som en bondeplager! Det er imidlertid påfaldende, at udviklingen med hovedgårdsoprettelser i området nok har været et århundrede forud for det øvrige land.

\section{Hertugtidens betydning for landbrugerne i Hørup og Ulkebøl sogne}

Tiden under de sønderborgske hertuger betegnes almindeligvis som et meget mørkt kapitel i historiebøgerne, hvor specielt hertugdømmets stamfader, hertug Hans den Yngre, har fået et selv for en godsherre meget dårligt eftermæle. Han karakteriseres således almindeligvis som en tyrannisk bondeplager, der under sine rideture udpegede de gårde, der skulle henlægges under hovedgårdene. $^{122}$ 
Som det fremgår af ovenstående, har der da også fundet en del nedlæggelser af bol sted i området, men kun i forbindelse med etableringen af Majbølgård er i gangværende driftsenheder ( 5 bol og 4 kåd) blevet ødelagt endda 18 år efter hertug Hans' død. I alle andre tilfælde synes der at være tale om landbrug, der lå øde eller må siges at have været små og urentable.

En stor del af de ødelagte øde bol er blevet henlagt under hovedgårdene. De kan næppe være udpeget under hertugens rideture, idet de lå i fællesskab og det må derfor formodes, at jorden i stedet er blevet omrebet og altså »flyttet « til andre agre, for at hovedgårdene kunne blive arronderet og få jord i nærheden.

Således betaltes afgifterne til skolen og til St. Jørgens hospital efter hertugtiden af flere fæstere end oprindelig fastsat i gavebrevene, ligesom også Sønderborg ladegård senere i tiden måtte betale for jord, der oprindelig havde hørt til skolen. ${ }^{123}$

Ligeledes har hertug Hans fået skyld for at have gjort bønder til kådnere, ${ }^{124}$ hvilket ikke var ualmindeligt $i$ kongeriget, men de eneste påviselige eksempler på, at dette er sket $i$ de to omhandlede sogne, findes $i$ forbindelse med nedlæggelsen af 3 bol i Mintebjerg og oprettelsen af Majbølgård under hertugens efterkommere.

Hertug Hans skulle også have tvangsforflyttet kådnere til Kegnæs, ${ }^{125}$ som ved hans overtagelse af hertugdømmet var bevokset med skov, og hvor der gik adskillige tusinde svin.

Landbrugerne havde oprindelig måttet fragte træ fra Kegnæs til udskibningshavnene, men denne tjenesteydelse var 1643 erstattet af en pengeydelse på 6 skilling. ${ }^{126}$ Det kan tænkes, at svinepasningen, skovhugsten og kørslerne er overtaget af kådnere, der omkring 1615 bosatte sig på halvøen, men egentlige tvangsdeportationer kan ikke påvises.

Hertug Hans har vel nok med rette fået skylden for at have frataget købstaden sin bymark, selv om det vel nok næppe skyldes straf for, at nogle borgere havde dræbt en af hans pager, og at ingen ville angive den skyldige. ${ }^{127}$

Hertugen synes dog at have respekteret allerede indhegnede løkker ${ }^{128}$ på lignende måde, som man tidligere havde gjort i Flensborg. ${ }^{29}$ Til gengæld synes borgerne i Sønderborg at have fået frataget deres græsningsret til selve bymarken, der er blevet henlagt under ladegården; de var derfor anvist på at leje græsningsret til et bestemt antal kreaturer hos landbrugerne i Kær, Ulkebøl og Sundsmark, hvilket hertugen præciserede i $1601 .{ }^{130}$

Dette må ses som et led $\mathrm{i}$ hertugens målrettede politik med at afgrænse borgerlig næring fra landbrug for ved en skarp adskillelse af disse to erhverv at styrke dem begge. Han gav borgerne håndværksmæssige og merkantile rettigheder mod at fratage købstaden marginaljorden, der blev henlagt under 


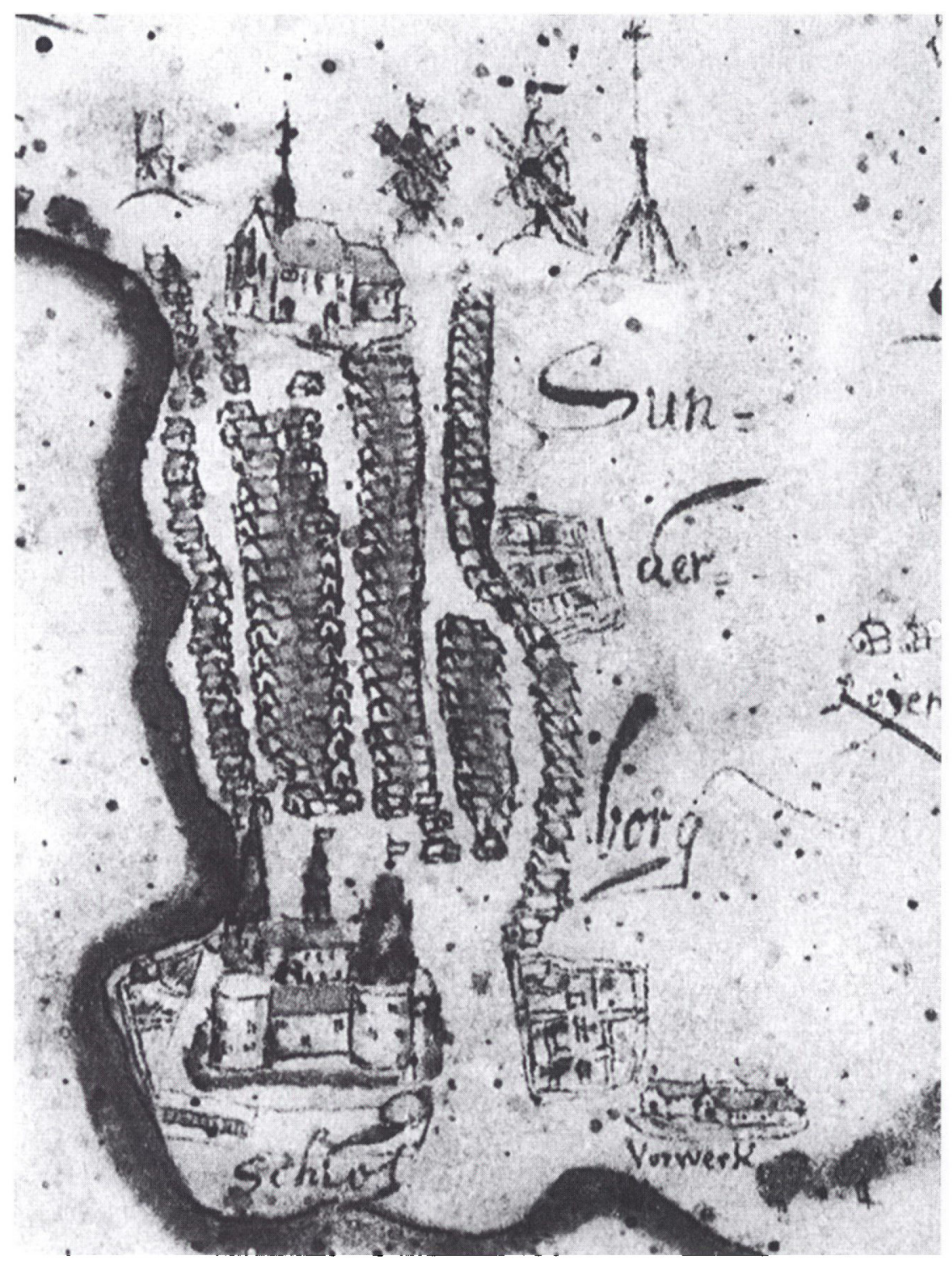

Sonderborg ladegård ses umiddelhart uden for Sonderhorg by på Heinrich Ottendorffs landkort fra 1655. Foto Det kgl. Bihliotek.

hovedgården samtidig med, at han ved at reducere borgernes mulighed for at drive landbrug styrkede bøndernes afsætningsmuligheder.

Præsterne klagede over, at hertugen henlagde flere bol under hovedgården 
uden at betale tiende herfor til områdets kirker. ${ }^{131}$ Dette er også rigtigt, men såvel Hørup som Ulkebøl sogne hørte under Fyns stift og måtte derfor respektere den danske lovgivning, og ifølge kong Christian III's håndfæstning var hovedgårdsjorden tiendefri, når blot en adelig ejer drev hovedgården for egen regning. ${ }^{132}$ Hertugen var altså juridisk berettiget hertil!

Ligeledes siger traditionen, at bønderne flygtede fra hertugens område ${ }^{133} \mathrm{og}$ at de tilbageblevne var forarmede på grund af hertugens hensynsløse godsherrestyre. ${ }^{134}$ Hertug Hans har utvivlsomt intensiveret hoveriet på sine hovedgårde længe før, at det blev almindeligt i Danmark, Men også mange andre steder (specielt $\mathrm{i}$ Holsten) blev hovedgårdsdriften intensiveret, og også dér flygtede mange landbrugere fra hjemstavnen. ${ }^{135}$ I 1614 blev det ved lov i hertugdømmerne forbudt købstæderne at yde hjælp til bortkomne godsbønder. ${ }^{136}$

I Holsten udviklede hoveriet sig fra ca. 1500 til livegenskab, ${ }^{137}$ og også på familien Ahlefeldts godser i Lundtoft herred - naboområdet til hertugdømmet Sønderborg - var der livegenskab. ${ }^{138}$ I den Glücksburgske del af hans tidligere område udviklede hoveriet sig ligeledes til livegenskab, ${ }^{139}$ men da det ikke kendes fra Als, må det være opstået efter 1622, hvor hertugdømmet blev delt. Der kendes enkelte eksempler på, at hertugerne af Sønderborg har reklameret undersåtter, der var undveget med redskaber og kvæg, som om de havde været livegne, men de er fra hhv. $1640 \mathrm{og} 1662^{140} \mathrm{og}$ altså efter hertug Hans' død.

Der kendes omvendt eksempler på, at hertugen har hjulpet forarmede bønder med at tilså deres agre eller eftergive dem et års afgift, ${ }^{141}$ hvilket heller ikke stemmer overens med det despotiske billede, eftertiden har tegnet.

Hertug Hans indtog - trods den manglende hylding fra stænderne - for sine undersåtter nærmest en regerende fyrstes stilling ved bl.a. at udstede forordninger og privilegier, præge mønter samt udøve den dømmende myndighed, men det er dog snarere som godsejer, at han vandt berømmelse. ${ }^{142}$ Hans efterkommere havde ikke den samme konjunkturbestemte medgang og deputaterne til deres mange børn, ${ }^{143}$ deres luksuriøse levned og manglende økonomiske formåen samt frem for alt krigenes udpining af befolkningen og skattetrykket gjorde, at tiden under hertug Hans' efterkommere blev væsentlig hårdere end under hertugdømmets berygtede grundlægger. Også det er træk, der genfindes andetsteds! $!^{144}$

De sønderborgske hertuger har dog ikke - som andre steder i hertugdømmerne ${ }^{145}$ - forsøgt at få møntens faldende værdi ${ }^{146}$ konverteret til større pengeafgifter, jfr. tabel 5, der viser udviklingen i penge- og naturalieydelser for et selvejerbol.

Ligeledes er det påfaldende, at der endnu ved de sønderborgske hertugers konkurs var $25 \%$ selvejere i området. Det var flere end i kongeriget; ${ }^{147}$ på Fyn faldt tallet således støt fra ca. 15\% ved reformationen for næsten at være 


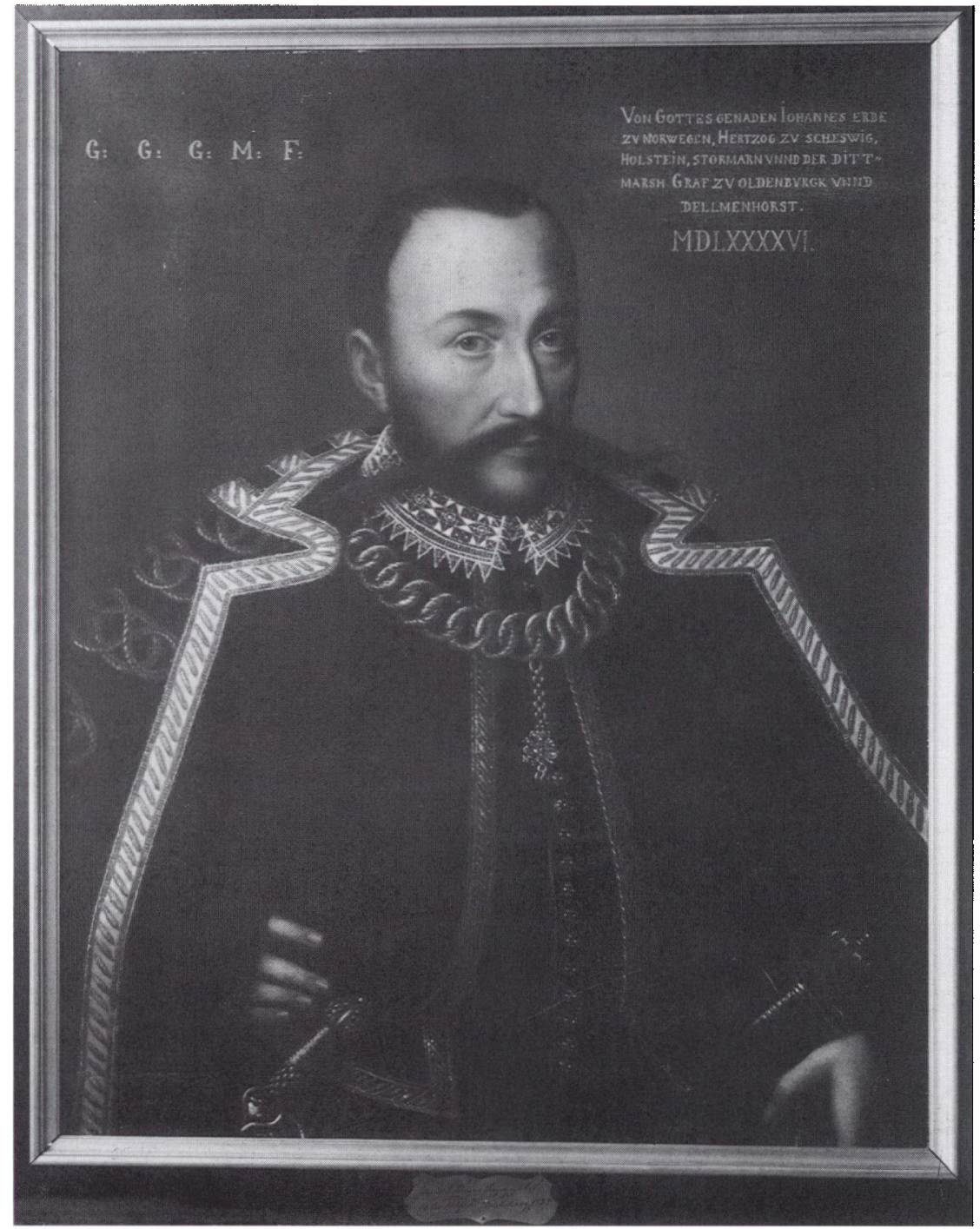

Hertug Hans den Yngre, 1596. Måske har eftertiden tegnet hans portrat som hondeplager mere sort end rimeligt, set i forhold til efterkommere og samtid. Efter maleri pd Glücksborg. 


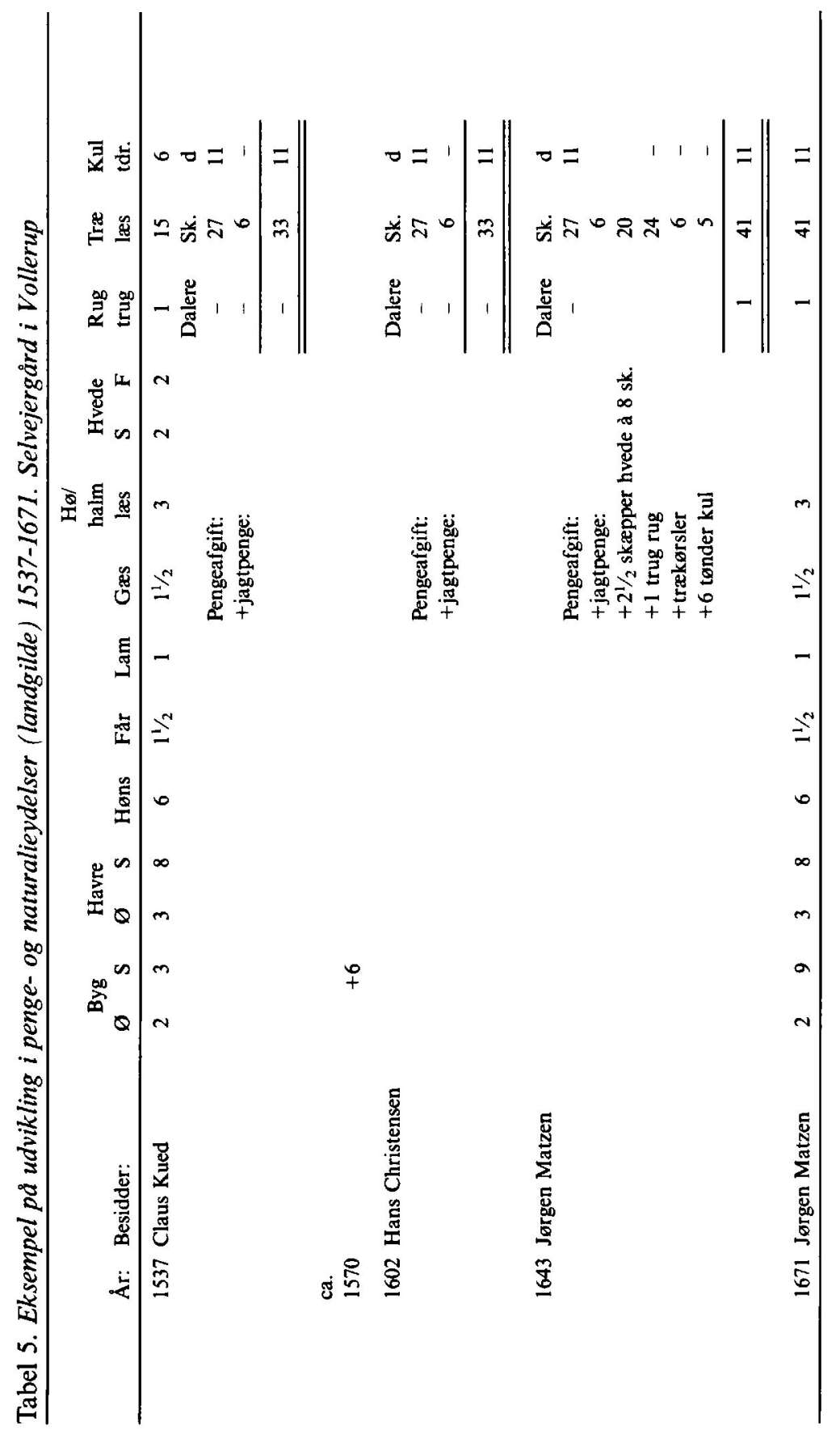




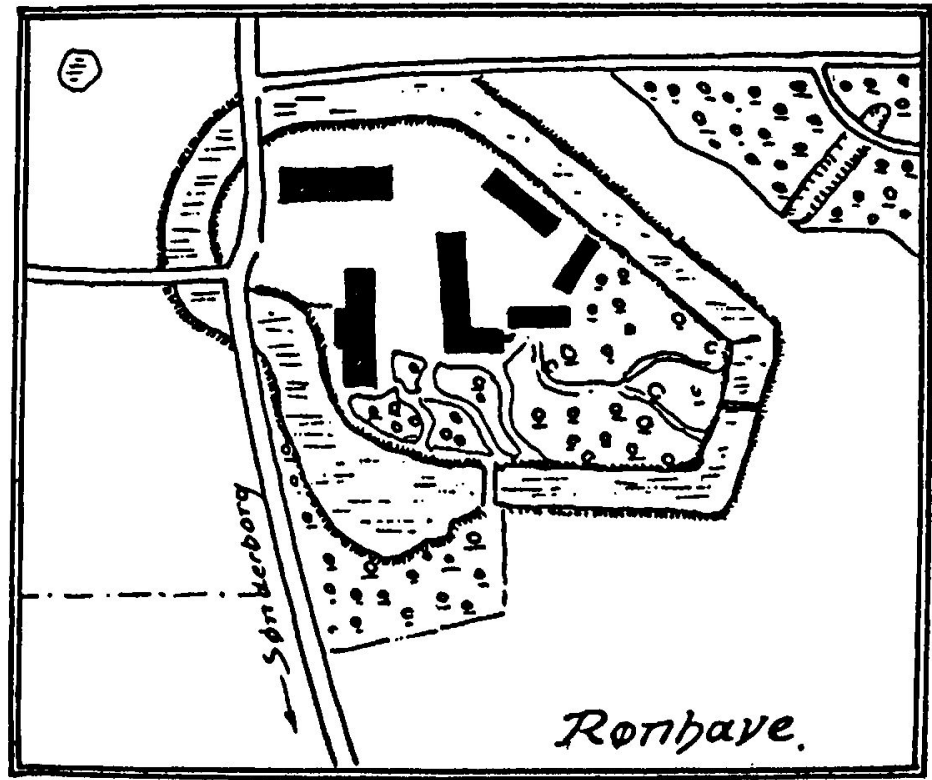

Om slagten Holcks herresade vidner voldstedet Ronhave, der stadig barer gdrdens nuvarende bygninger. Voldstedet har form af en trapez, $250 \mathrm{~m}$ lang, $60 \mathrm{~m}$ bred mod ost og $120 \mathrm{~m} i$ vest omgivet af en smal vandgrav. Tegning af Jens Raben i Fra Ulkebol sogn (Fra Als og Sundeved XV).

forsvundet ved nærværende periodes udløb. ${ }^{148}$ I samme periode er der kun nedlagt tre selvejerbol i de to undersøgte sogne - i Ulkebøl, Sundsmark og Mintebjerg - og med øde- og nedlæggelserne af fæstebol in mente betyder dette rent faktisk, at selvejerprocenten er steget i perioden!

Også dette må ses i lyset af de sønderborgske hertugers politik: Man forsøgte at blive ejer af alle driftsenheder $i$ området, for derved at muliggøre en intensiv hovedgårdsdrift. Men samtidig var man interesseret $i$ at bevare landgildeydelserne - og netop i denne forbindelse spillede selvejerne med de højeste afgifter den største rolle!

Sammenfattende må man nok sige, at udviklingen fra middelalderens ophør til de sønderborgske hertugers konkurs har vist en markant stramning af landbrugernes vilkår. De fleste gårdnedlæggelser er imidlertid ikke foregået under hertug Hans den Yngre som hidtil antaget, men under dennes efterkommere og intet tyder på, at forholdene på Sydals, der takket være nærheden til hertugens hovedsæde Sønderborg nok har været mere udsat end de lidt fjernere liggende egne, har været værre end andre steder $i$ landet.

Til gengæld synes hertugtidens tiltag at have været så kategoriske, at der ikke har været behov for at ændre landsbyernes struktur i den følgende tid 
indtil udskiftningstiden. Og den kom først mere end et århundrede efter konkursen.

\section{NOTER}

Forkortelser:

LAAa Landsarkivet, Aabenraa

LASH Landesarchiv Schleswig-Holstein, Gottorp

RA Rigsarkivet, København

1. Henning Mathiesen: Hertugens Folk, Aabenraa 1992.

2. Aksel E. Christensen: Problemer vedr. adel og hovedgårde i dansk - senmiddelalder i Danmark, Norden og Ostersøen, Udvalgte Afhandlinger, København 1976 (side 228-242).

3. Urkundensamming der Schleswig-Holstein-Lauenburgischen Gesellschaft für vaterländische Geschichte, Band 2, Kiel 1842-58 (side 385-390).

4. Schleswig-Holsteinische Regesten und Urkunden, Band 6, Teil 2, Neumünster 1962-71 (side 1077) samt E. Pontoppidan: Annales Ecclesia Danica, Bind II, København 1744 (side 259).

5. E.Pontoppidan: Annales Ecclesia Danica, Bind II, København.

6. Urkundensammlung der Gesellschaft für Schleswig-Holstein-Lauenburgische Geschichte, Band IV (Registrum König Christian des Ersten), Kiel 1875 (side 403).

7. H. C.P.Sejdelin: Diplomatarium Flensborgense, bind 1, København 1865 (side 87).

8. do. (side 113).

9. do. (side 94).

10. RA, Tyske kancelli, pakke A $98 \mathrm{I}$, akter vedr. forhandlinger med enkedronning Dorothea og Hans den Yngre om den gejstlige jurisdiktion på Als og Ærø m.m. 1567-73 (28.april 1573).

11. J. Raben: Fra Ulkebøl Sogn, Sønderborg uden år (side 60).

12. Illustration i do. (side 53).

13. H.C.P.Sejdelin: Diplomatarium Flensborgense, bind 2, København 1873 (side 29).

14. Om slægterne Holck og Sture: A.D.Jørgensen: Herregårdene på Als i det 16. århundrede i Historiske Afhandlinger, Bind IV, København 1899 (side 462-494) (også i Sønderjydske Aarboger, Flensborg 1897 (side 96-137) og Henrik Fangel: Herremænd på Als og Sundeved i middelalderen og 1500-tallet i: Jørgen Slettebo (red.): Adel og hertuger på Als og Sundeved, Sønderborg 1979 (side 13-21).

15. Repertorium Diplomaticum Regni Danici Midiavalis, series secunda, København 1934 (side 207).

16. De aldste danske Arkivregistraturer, bind 1, København 1910 (side 12).

17. RA, Slesvigske og holstenske regnskaber før 1580, Kongens arkiv, Sønderborg og Nordborg amters regnskaber ca. $1500,1514,1518$ og 1524.

18. do., Sønderborg og Nordborg amters naturalieregnskaber 1534-37/1545.

19. Om begreberne gods- og grundherskab se: Jens Jessen: Die Entstehung und Entwicklung der Gutswirtschaft in Schleswig-Holstein zu den Beginn der Agrarreformen i Zeitschrift der Gesellschaft für Schleswig-Holsteinische Geschichte, Band 51, Kiel 1922.

20. R. Mejborg: Nordiske Bandergaarde $i$ det XVIde og XVIIde Aarhundrede. Tillag til forste Bind, København 1893 (side 51).

21. Chr. L. E. v. Stemann: Geschichte des öffentlichen und Privat-Rechts des Herzogthums Schleswig, Erster Theil, Kopenhagen 1866 (side 237).

22. J.P.Trap: Danmark, bind X,3, Abenrä-Sønderborg Amter, 5. udgave, København 1967 (side 1227) jfr. C. A.Christensen: Krisen på Slesvig Domkapitels jordegods 1352-1437 i Historisk Tidsskrift, 11. rakke, bind 6, København 1960-62 (side 161-244).

23. Diplomatarium Danicum, 2. rakke, bind 1, Kobenhavn 1948 (side 18).

24. Kr. Erslev: Konge og Lensmand $i$ det sextende Aarhundrede, København 1879 (side 111-112).

25. Chr. L. E. v. Stemann note 21 anf. arb. (side 237). 
26. Diplomaticum Danicum, 2. rakke bind 6, (side 81).

27. Ole Harck: De slesvigske byers ældste historie i Sønderjyske arrbøger 1983, side 39-40.

28. Erich Hoffmann: Beiträge zur Geschichte der Stadt Schleswig i Zeitschrift der Gesellschaft für Schleswig-Holsteinische Geschichte, Bd. 105, Neumünster 1980 (side 67), jfr. Thomas Riis: Sct. Nikolai i Svensborg - en købmandskirke? i Fynske minder 1972 (side 67-76).

29. Ole Harck anf. arb. 39-40.

30. Registrum König Christian des Ersten, Kiel 1875 (side 83).

31. Repertorium Diplomaticum Regni Danici Medievalis (side 603).

32. Acta Pontificum Danica, bind IV (side 402-403).

33. A. D. Jørgensen anf. arb. (side 467).

34. Vilhelm la Cour i Senderjyllands Historie, bind II, København 1937-39 (side 326).

35. LASH, Abt. 15 Nr. 2060, Das adelige Landgericht, Streitigkeiten zwischen Herzog Johan der Jüngere auf der eine und Claus und Henneke Meinstorf auf der andere Seite 1594-98.

36. H. N. A. Jensen: Schleswig-Holsteinische Kirchengeschichte, Bd. III, Kiel 1877 (side 335).

37. A. D. Jørgensen anf. arb. (side 485).

38. H.C.P. Sejdelin anf. arb. bind 2 (side 26-32); der betaltes 1 mark pr. plov.

39. RA, Slesvigske og holstenske regnskaber før 1580, Kongens arkiv, Sønderborg og Nordborg amters pengeregnskaber 1533-36 (i en fortegnelse over plovskat fra adelen 1534 regnes der med 3 mark pr. plov).

40. A. D. Jørgensen anf. arb. (side 470).

41. "Christiani III gloriossima memoria fundation Sub dato 6 Mai 1550 - afskrift i LAAa, Sønderborg præstearkiv, pakke D (forhandlingsprotokol for kirke- og skolekollegiet 1755-1870).

42. 12. april 155I, jfr. H.C. P. Sejdelin anf. arb. bind 2 (side 500).

43. $\mathrm{Kr}$. Erslev anf. arb. (side $91 \mathrm{ff}$.).

44. Jfr. note 39.

45. "Vorwarck « er plattysk for "Vorwerk «, der betegner en mindre ladegård.

46. RA, Slesvigske og holstenske regnskaber før 1580, kongens arkiv, reviderede regnskaber, Sønderborg og Nordborg amters pengeregnskaber 1537-38/1540-43.

47. Wolfgang Prange: Die Anfänge der grossen Agrarreformen in Schleswig-Holstein bis 1771, Neumünster 1971 (side 693).

48. Paul von Hedemann-Heespen: Die Herzogthümer Schleswig-Holstein und die Neuzeit, Kiel 1926 (side 239).

49. Vilhelm la Cour i note 34 anf. arb. (side 197).

50. Johanne Skovgaard i note 34 anf. arb. (side 408) samt Chr.L.E.v. Stemann: Geschichte des offentlichen und Privat-Rechts des Herzogthum Schleswig. Zweiter Theil, København 1866 (side 252).

51. L. Laursen (red.): Danmark-Norges Traktater, bind II, København 1912 (side 110 ff.).

52. Apologia Des Fürstlichen Hauses Schleswigh/Holstein Sonderburgischer Linien, samt und sonders, Wieder Den ... durch D. Caspar Dangkwerth ... in dessen in Druck ausgelassener Landesbeschreibung der Fürstenthümber Schleswigh/Holstein angeführten falschen Bericht, Lübeck 1654 (Beylage No. 1).

53. F. v. Krogh: Beiträge zur älteren Geschichte des Hauses Holstein-Sonderburg, Berlin 1877 (side 9).

54. Corpus Statutorum Slesvicensium, Band III, 2. Abteilung, Schleswig 1812 (side 187-189).

55. Det er påfaldende, at de gårde, hvis kornydelser gik til kapellanen i Sønderborg og som stammede fra Peter Stød, ikke nævnes i denne forbindelse. Gården i Notmarkskov (Padholm) er således overført til Sture-slægtens hovedgård Helvedgård, og det synes på basis af afgifterne fra en senere tidsalder (1722), som om ejendommene i Sønderborg er overdraget til Baltzer Karberg og drevet sammen med godskomplekset "Ulkebølgård«, som han havde arvet efter Drude Høk. Disse adelige synes således også at have fået del i kirkegodset. Ulkebølgård kan $\mathrm{i}$ øvrigt ikke være identisk med gården "Bagmose" som antaget af Jens Raben (note 11 anf. arb. side 60), idet gården lå under St. Erasmi vikariet ved St. Nicolai-kirken og først i forbindelse med et mageskifte med kongen i 1584 er blevet overdraget hertug Hans den Yngre. 
56. jfr. note 10 (ingsvidne af 4 . oktober 1572 ).

57. do., brev af 8 . juli 1573 fra Frederik II.

58. jfr. note 41 .

59. F. v. Krogh anf. arb. (side 18 ).

60. L. Laursen note $5 \mathrm{I}$ anf. arb. (side $596 \mathrm{ff}$.).

61. RA, De sønderjyske fyrstearkiver, hertug Hans den Yngre, pergamentbreve Aa 6, mageskifte af 6. marts 1584 mellem Frederik 2 og Hertug Hans den Yngre - ekstrakt i: L. Laursen (red): Kronens skoder paa afhandet og erhvervet Jordegods i Danmark fra Reformationen til Nutiden, 1. Bind 1538-1648, København 1892 (side 277).

62. Jørgen Steen Jensen: Hertug Hans den Yngre, Sønderborg 1971 (side 34).

63. RA, De sønderjyske fyrstearkiver, Hans den Yngre, adkomstbreve C 4, skøde af 6. januar 1590.

64. L. Laursen note 51 (side 598).

65. RA, De sønderjyske fyrstearkiver, Hans den Yngre, adskomstbreve C 4, skøde af 6.januar 1590.

66. Jørgen Steen Jensen anf. arb. (side 43).

67. Schriften des Vereins für Schleswig-Holsteinische Kirchengeschichte, IV Band, Kiel 1906-08 (side 205).

68. LAAa, Sønderborg byarkiv, St. Jørgens hospital, Erdbuch und Protocollum, Renovirt Anno 1747 den 16. Märtz.

69. Arkivet på Deutsch Nienhof, Holstein, nr. 250a, pengeregnskab fra Hans den Yngres tid.

70. jfr. note 18 .

71. Gunnar Olsen: Hovedgdrd og bondegård, København 1957 (side 52).

72. jfr. note 61 .

73. Fridlev Skrubbeltrang: Husmand og Inderste, København 1940 (side $35 \mathrm{ff}$.).

74. jfr. note 10.

75. do.

76. jfr. note 41 resp. note 54 (side 187-189).

77. LAAa, Sønderborg amtstue, pakke 88, jordebog over Sønderborg amt 1722.

78. J. Raben anf. arb. (side 60).

79. RA, De sønderjyske fyrstearkiver, Hans den Yngre, sager på papir, pakke 16, svineregnskab for skovene i Sundeved og på Als 1604.

80. LAAa, Ulkebøl præstearkiv, nr. Cl, kirkeregnskabsbog 1589-1691.

81. Henrik Ussing: Det gamle Als, København 1926 (side 250) nævner elleve.

82. jfr. note 79 .

83. Jørgen Slettebo: Adel, slotte og voldsteder i Bogen om Als, Aabenraa 1956 (side 165).

84. do. (side 34-35).

85. Testamentet er gengivet i F. v. Krogh anf. arb. (side 137-138).

86. O. Nielsen i Alses Overgivelse til de kejserlige Tropper i Krigen 1627-29 i Historisk Tidsskrift. 3. Rakke, Bind VI, Kabenhavn 1867 (side 68).

87. Johanne Skovgaard i Senderborg Bys Historie, Bind I, Sønderborg 1960 (side 31).

88. Johanne Skovgaard i Sonderjyllands Historie, bind III, København 1940-42 (side 14).

89. F. v. Krogh anf. arb. (side 35).

90. Johanne Skovgaard i note 87 anf. arb. (side 32).

91. F.v. Krogh anf. arb. (side 35).

92. O. Nielsen anf. arb. (side 83).

93. A. D. Jørgensen anf. arb. (side 462).

94. F. v. Krogh anf. arb. (side 36 ).

95. Johanne Skovgaard i note 87 anf. arb. (side 40).

96. do. (side 33-34).

97. do. (side 35).

98. Frede Terkelsen: Als i Krigstider i note 83 anf. arb. (side 282).

99. Stanislw Rosznecki: Polakkerne i Danmark efter Jan Paseks Erindringer, København 1896 (side 129). 
100. do. (side 130 ).

101. P. F. Rist: Als's Erobring 1658 i Historisk Arkiv, Bind II, København 1885 (side 237).

102. jfr. note 68 .

103. Henrik Ussing anf. arb. (side 253).

104. do. (side 254).

105. Johanne Skovgaard i note 87 anf. arb. (side 38 ).

106. Frede Terkelsen i note 83 anf. arb. (side 282).

107. Det drejede sig især om Philipp v. Ahlefeldt, oberst Hans Löwenklau og Gosche v. Thienen, jfr. P. v. Hedemann-Heespen: Kapitalbesitz, Lehngüter, Landesverteidigung, Hufenzahl und Augustenburg i Zeitschrift der Gesellscahft für Schleswig-Holsteinische Geschichte, Band 45, Leipzig 1915 (side 345).

108. P: Lauridsen: Slesvig og Kronen 1660-1671, København 1906 (side 82).

109. do. (side 83).

110. do.

111. RA, De sønderjyske fyrstearkiver, Sønderborg, sager på papir, pakke 8, regnskab over faste pengeafgifter 1642-44.

112. LAAa, Sønderborg amtstue, pakke 89, jordebog over Sonderborg amt ca. 1671.

113. P. v. Hedemann: Beiträge zur älteren Geschichte des Hauses Holstein-Sonderburg i Zeitschrift der Gesellschaft für Schleswig-Holstein-Lauenburgische Geschichte, Band 31, Kiel 1901 (side 36)

114. jfr. note 79 .

115. Fridlev Skrubbeltrang: Det danske landbosamfund 1500-1800, København 1978 (side 83).

116. LAAa, Sønderborg byarkiv, pakke 9, diverse ældre breve vedr. Sønderborg (19. februar 1626).

117. jfr. note 80.

118. LAAa, Sønderborg amtsarkiv, pakke 207, forskellige landvæsenssager, sager vedr. landsbyfællesskab, hegnsstridigheder m.v. 1634-1754.

119. Henning Mathiesen anf. arb. (side 157).

120. Gunnar Olsen anf. arb. (side 171-172).

121. Erland Porsmose: De fynske landsbyers historie i dyrkningsfallesskabets tid, Odense 1987 (side 159).

122. Henrik Ussing anf. arb. (side 250).

123. LAAa, Sønderborg amtstue, pakke 76, registre over kontribution og fæsteafgifter.

124. Jørgen Slettebo note 83 anf. arb. (side 166).

125. do. (side 167).

126. jfr. note 111 .

127. Henrik Ussing anf. arb. (side 251), Johanne Skovgaard i note 87 anf. arb. (side 26).

128. Pengeregnskabet fra ca. 1602 (jfr. note 69) nævner en del borgere (bl.a. byens embedsmænd), der betalte "Bekentnisgelt« for deres haver, kålgårde og anden jord ved Sønderborg.

129. P. Kr. Iversen i Flensborg Bys Historie, Bind I, København 1953 (side 337).

130. LAAa, Sønderborg byarkiv, pakke 7, breve fra landsherrerne 1554-1665 (mandat af 24. september 1601 ).

131. Jørgen Steen Jensen anf. arb (side 46), jfr. note 10.

132. Gunnar Olsen anf. arb. (side 61).

133. Johanne Skovgaard i note 88 anf. arb. (side 388).

134. Troels Fink: Rids af Sonderjyllands Historie, 3. udgave, København 1955 (side 90).

135. Johanne Skovgaard i note 88 anf. arb. (side 63).

136. H.V.Gregersen: Slesvig og Holsten for 1830, København 1981 (side 283), Johan Hvidtfeldt: Kampen om ophavelsen af livegenskabet i Slesvig og Holsten, Aabenraa 1983 (side 18).

137. Johan Hvidtfeldt anf. arb. (side 17).

138. do. (side 18).

139. do. (side 19).

140. do.

141. Jørgen Steen Jensen anf. arb. (side 47).

142. Johanne Skovgaard i note 88 anf. arb. (side 386). 
143. Paul von Hedemann-Heespen note 48 anf. arb. (side 300).

144. Johanne Skovgaard i note 88 anf. arb. (side 74).

145. do.

146. Emil Waschinski: Währung. Preisentwicklung und Kaufkraft des Geldes in Schlesurig-Holstein von 1226-1864, Neumünster 1952 (side 30 ff.).

147. Johanne Skovgaard i note 34 anf. arb. (side 408).

148. Erland Porsmose anf. arb. (side 188). 